\title{
$\diamond$ 合同討論
}

\section{国際経済学の根本問題}

$\begin{array}{lllll}\text { 座 長 名 } & \text { 和 } & \text { 統 } & \text { 一 } \\ \text { 副座長 } & \text { 松 } & \text { 井 } & & \text { 清 } \\ & \text { 北 } & \text { 川 } & \text { 一 雄 }\end{array}$

討論者堀晋作川尻武赤松要 吉信肃行, 沢健三麻田四郎

杉本昭七渡辺太郎入汇猪太郎

山田隆士 小島清発言順)

本多健吉柴田政利

矢内原勝森本憲夫

天野明弘金田近二

三辺信夫大来佐武郎

昭和 41 年 10 月 於関西大学

第二五回大会 


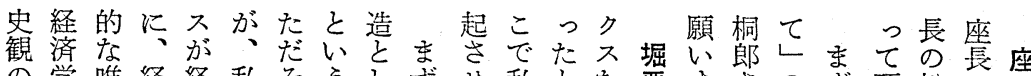

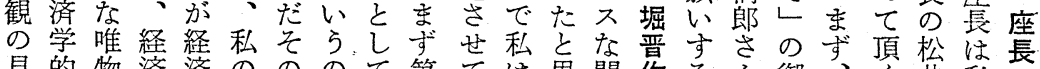
見的物済済のののて第ては思問作るん御、宑私

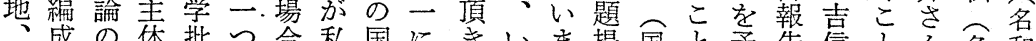
成の体批つ合私国にきいま提国々予告信之え名和

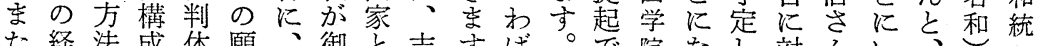
た経法成体願、御々吉すば。で院なし対えいく和 は済に体采いこ報い信。”もあ大りて求のた本でこ

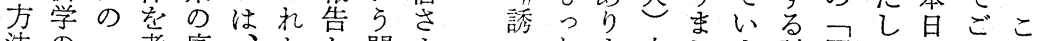
法のっ考序、かか問えいと吉しま討国まのされれ が体と察言下らら題は、水前す信たし諭際し午いか

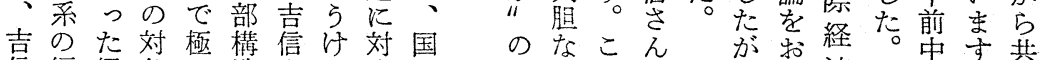
信繧経象め造さたす家 さ成済にてとん理るの んの学す簡上が解 一下 のプのる潔部展で貫部 方ラ方場に構開市乙構 法ン法合述造さりた造 でででの心゙の执、批华 あ⿱亠巾口心て問る全判 もるり打題と食をま っと、ばり思同展た 文いま唯ま、心感開は 胆唯々史上儿ま方部 に物の観うっす。た構

上問れの

う題は御 なの極報 意展め告 味開て医 でを禁 挍欲 こ願的め $\downarrow$ 小なて でし御オ 問た報 1 題い告り 提无市
願 済 御少学 都しに 合ま 掠 にすけ 上。る り 討 国 堀論家 晋者範 作と矌 えてぬ に森く” お田っ
中共 の 占通 座 昨 顥 の 日 の 北の共 川午同 さ後討 んの 論 に共に 副通入 座 諭 り 長題亦 に

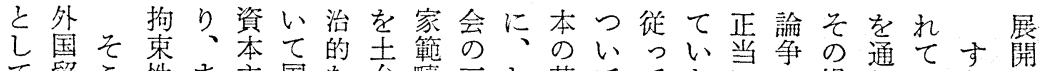

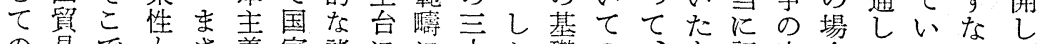

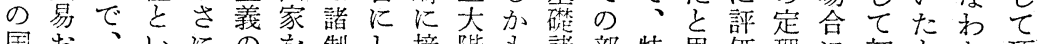

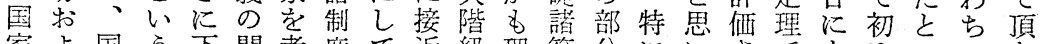
家よ国５下問考度て近級理範分に心さでもめこマき

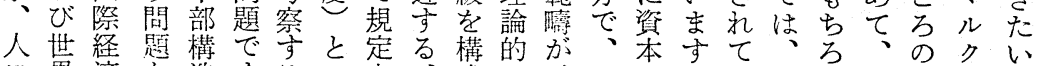

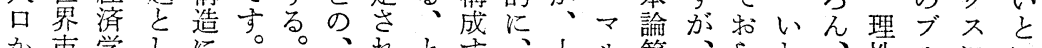

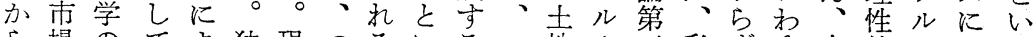

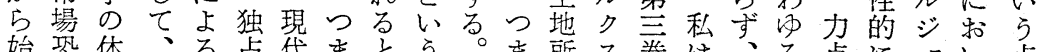

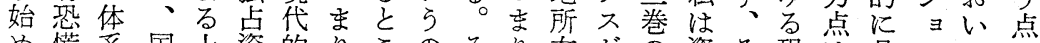
め慌采国上資的りこのそり有が資そ現点具了て点 なへ化家部本にブろがの資恶省資本の衡下体社はす

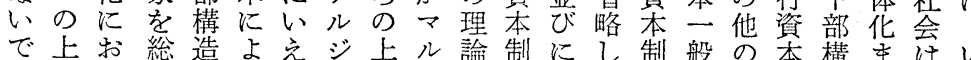
で上お総造よ怠卡儿諭制にし制般の本構まはい

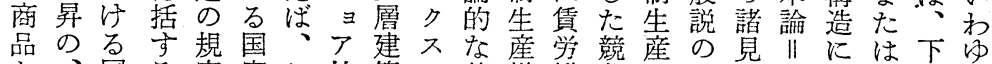
か、国る芫家こ社築の整梾偅争に見解資市理部る

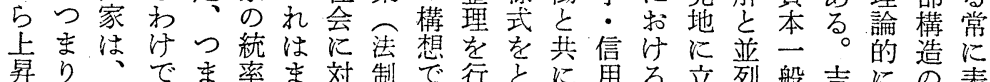
算私ず率亦対制で行々に角る立列般吉にの表

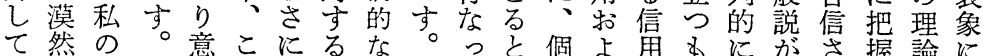
て然者こにるなっっと個よ用もにがさ握諭に 識れ国関らこたこ別びのの紹必几さ的浮 くるでのする家係びの上ろ具株役で介ずのれなか

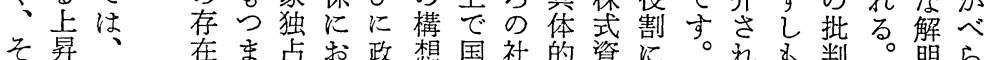




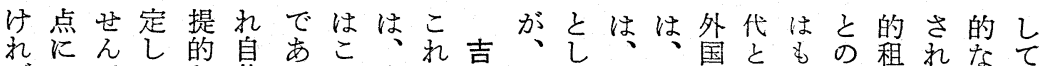
ばっでてな体っの唯は信現て外こ㙺いち有税て惁初 合々いし々女独た問物下肃在の国の易っう機制い惟め れてたりの立か題史部捅の国賢よ。たん的度るにて

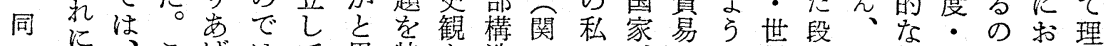
㳔こげは思特告西のがへな界階重統国でい性

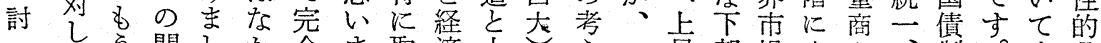

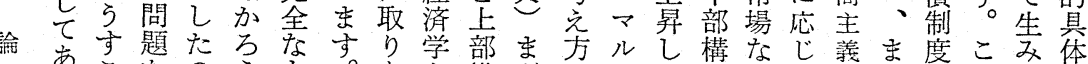
らこをの 5 す。あと構ずでクな造らて段だれだた

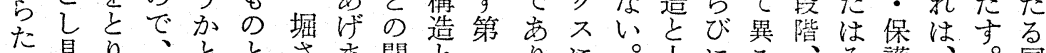

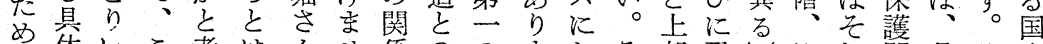
め体いこ考はんせ係の

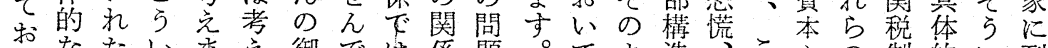
答なたいま御では係題。てょ造しこ主の制的い到

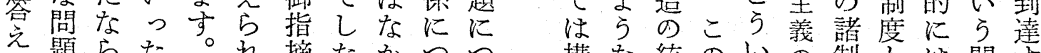
題らた。机摘たからっ構な統のい势制文は問等

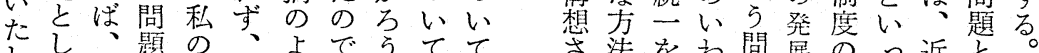

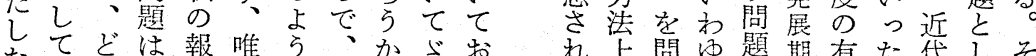

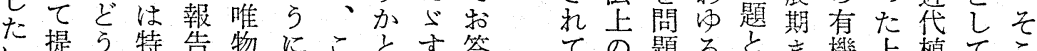

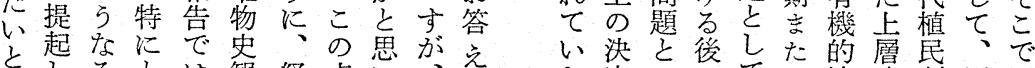

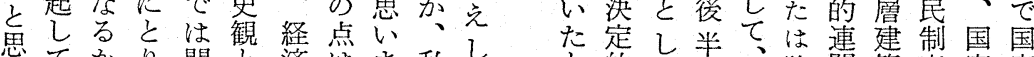

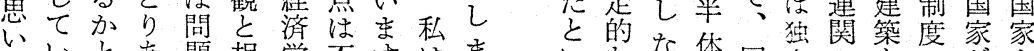

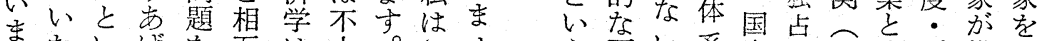

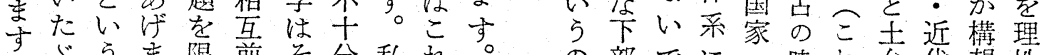
○一 5 ま限前そ分私れ の部でに・時れ台代想性

て諭国私らうもな技すにる打行がいのに完りま

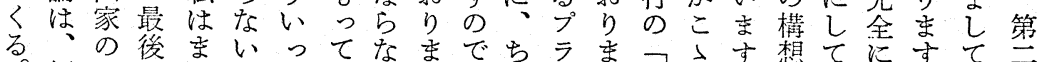

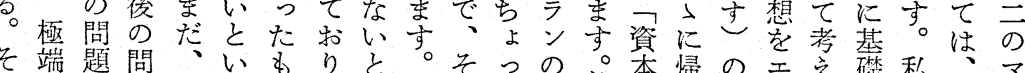

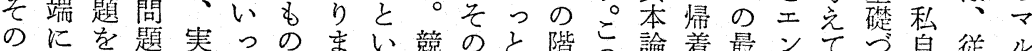

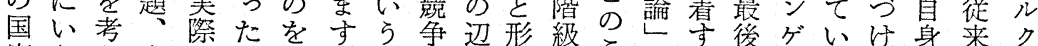

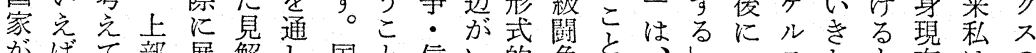

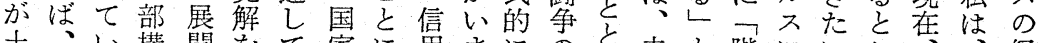
土心構開をて家に角まにのと未と階に心こ経 台前く造す私、独つ。私は位子完い級畫々万資資済

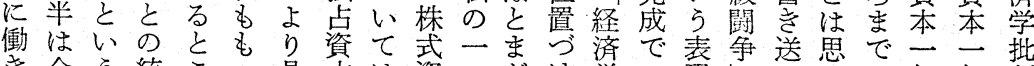

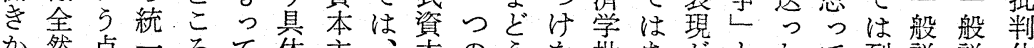
か然点一ろて体主、本のらを批あかとたて到説説体

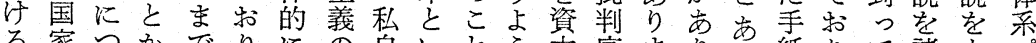

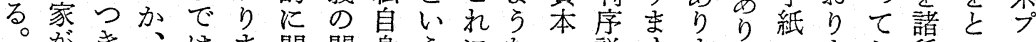

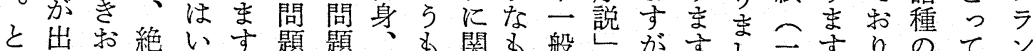

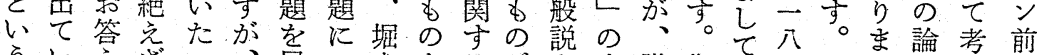

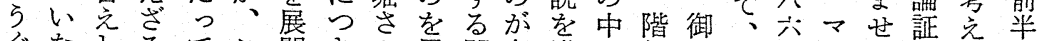
ぐなしるてこ開きん展問存進で級承公ルん芷先の あく想おれてまと開題在めの闘知名年クが実き問

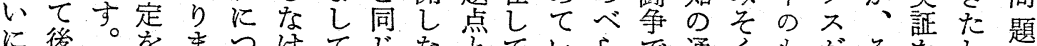

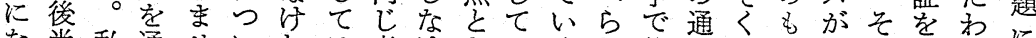

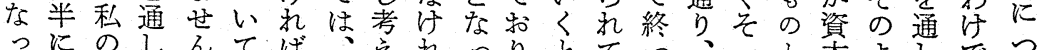

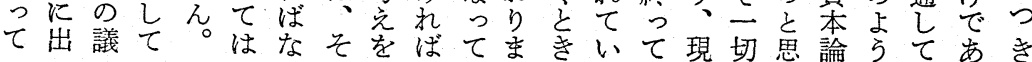




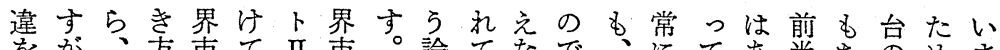
座をが、方市てIII市。論てなで、にてあ半ちのめま 長持、こを場、の場こ理いいあ国考きりにらほにす。

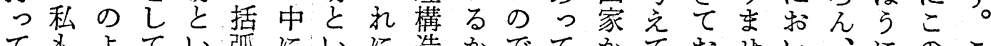

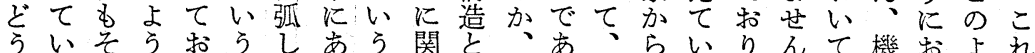

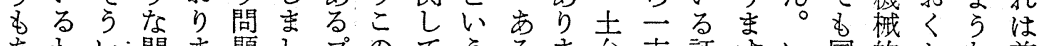
あわい問ま題しプのてらるま台方証すい国的かな前 り汀う題すをてラ問與観いすか的拠。わ家に、表半 がで点提。ほ、ン題味点はがらにでこばの理上現と とはに起こうそにをのか、、のは机問解部に後 うあるうりのお市らとた作台なは念題で構な半 ごりき行いこ中いつるはれだ用にいやのがき造っの ざまならんにて経の、な委対かは先まな性

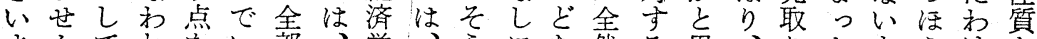

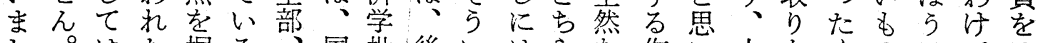
し。恃た堀る。国批後いはらな作心上をくのにでは

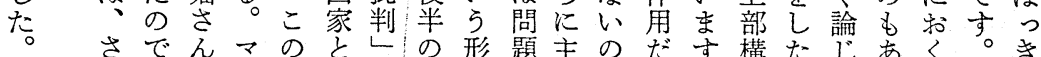

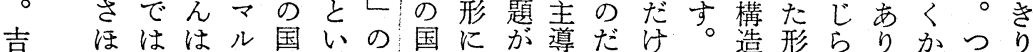

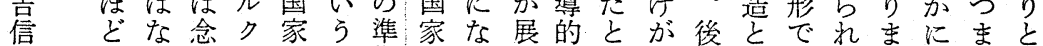

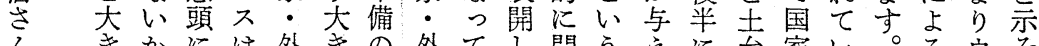
んきかには外きの外てし問う党に台家い。るウそ

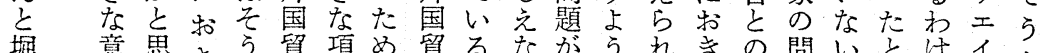
堀意思きう留項め留るながうれきの問いとけイを さ見 5 い易自の易わい論飞てま関題わ兄でトと んののなう・を人・忖とじはいし係が深すをす の 相でが書世設 1 世でいら考るてを入で、。土る

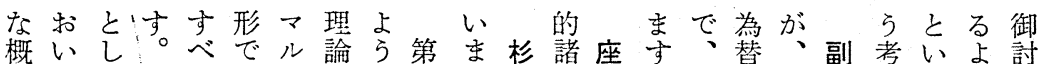

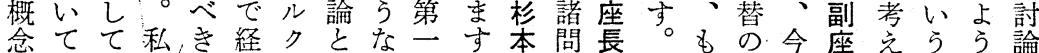

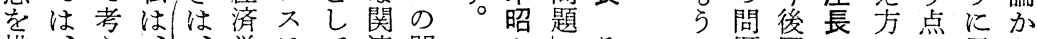

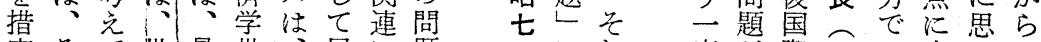

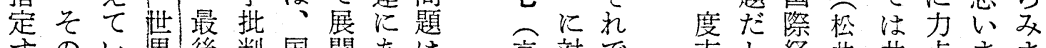

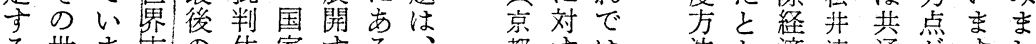
る世ま市の体家する

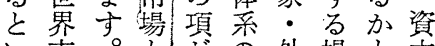
い市。と忐の外場と本 $\zeta$ 場 $、$ W 後国 合い輸 こおル5 界半貿に5出 とょク市市体易は点論 がびスの場系お特にの 恐がを特を占特展 そ慌分流よ考びにい開 のと析通びえ世こてが 時いし過恐て界問ざ、 代う程慌い市閴す。経

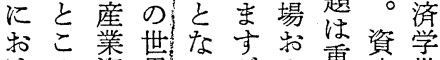

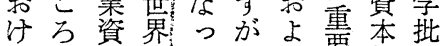
る华的て、び要輸判

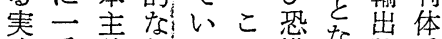
践番義相るっ谎な論采 的具段互こでと年を的

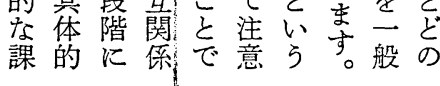

都すは

大る 討杉

山論本

田をさ さおん 几願飞 の い 御乙山 報ま田 告 寸 に。

き资

三点本

お出

教の

願理 法喻世済清通がすし 的界にたの岛 な市期だほ、た御 反場待今 らと、両 省恐しの がし下氏 を慌た論ずて部の すのい争つ、構間 る問ののと資造で と題は問多本とは いを、題い一し、 万具後もよ般て大 仕体半大亏説の体 事的体切にに国意 がに亲だ思重家䚁 必展をとい点観が 要開思ま学学接 たすた心す。お排近 思る 主ま

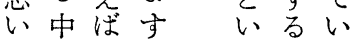


をいいかのての上が、り資でなまを最場化考は題

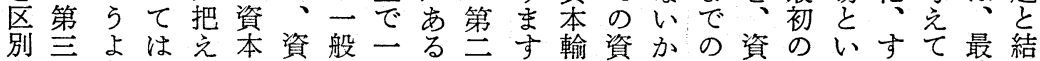

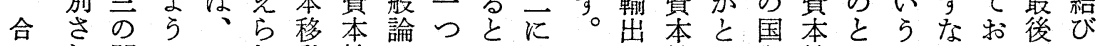
れ問にこれ動輸をのい問の輸考際輸こよわりにつ

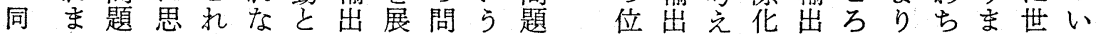

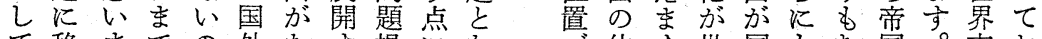

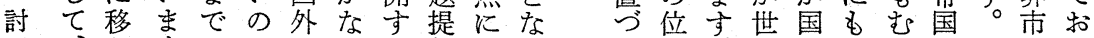

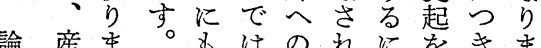
産ま。るはのれにをきま

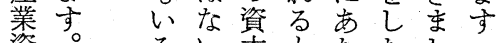
資。るい本とたたし二 本山心か輸い口いて般

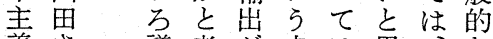
義さ議考が点は思、な 段ん論光、で、い私資 階は架る何す国ます本 で、かか。内卞同輸 は貨さら平さで。感出

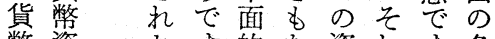
幣資たす的な資机す条 資本の。な㚈は。件 本とでこもれ移してを 過現はののば動資か考 剩実な問と文本し党 が资い題し国占輸、る

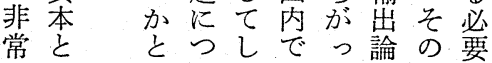
江置。界際っ ᄂ主こ場り と学を的てろ義れ交 はけの蔽にき世段によそ 々よ5網て界階対びの 自々時のお経をし恐た かレな期目り済分ま慌め ら1意飞の要と析しが、

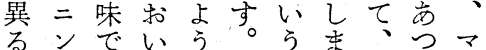
のの、てに私好列かル で帝、必広はのた強方ク は国ル要が世をし間れス な主ク吃界分、でたの い義スさて経析二ののプ か論のれ、済のン世でラ とのプる生と条は界はン 考なラ概産い項ななた 完かン念のうの世恣いお てでので側多一界資かい おの中は面の番市本とて

な場決と易はいは経引輸形るめて思本学孔輸飞 5 合乙思の、は済山点出態意に拈心はすて乞出重 なにてい中批方資学田に上上味、りま価貨いてが要 いは無まの判法本批隆疑のので貨ます值幣る拈非で の、関す生体化輸判吉問特区当幣す。破資よさ常市

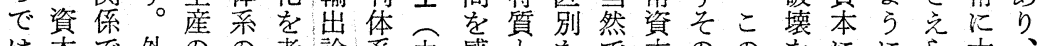
は本で外のの考論系中感とをで本ののをににら大、

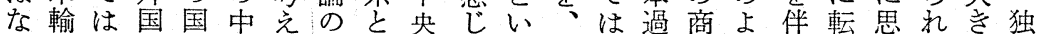

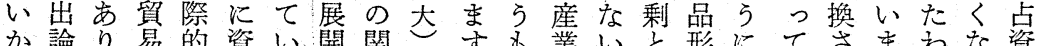

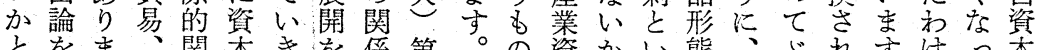

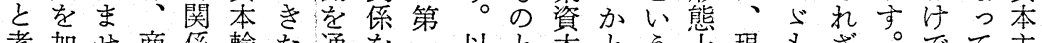

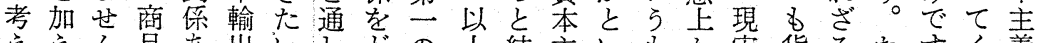

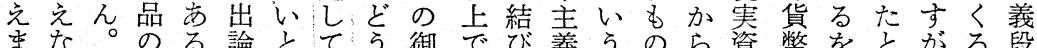
まな。のる論とてら御でび義うのら資幣をとがる段

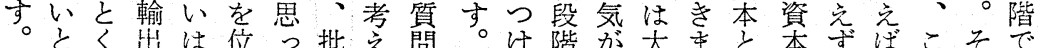
乙出は位つ批兄問 こ䒠国々国置て判るは 点際際て分けり采资 に汾資業るまのの本 関は業本之卞上揞 連理の輸いす。憳出 乙論展出 5 机私具称論 ての開点ばの体での 杉方竞考市外考华し展 本花考学年国えあ。開 さ沉るはか貿でる私と

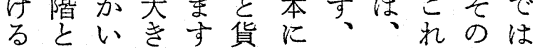
こ独たく特幣転特現に根産 と占しな殊資換に寒は拠業 が資まる性本さ恐資いを資

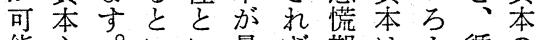
能主。いい景さ期はん循の 加義々らっ気るとそな環形 ぞ段のこた循をはの問過態 万階意々稿方性題程で かの味はの上な現格がのの と資で、の持い実上含問資 い本、あたっと資絶ま題本 
瞡よ剩いで本め等で国本明の資方問の二5済点几

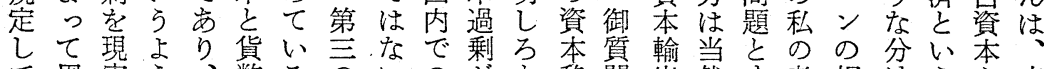

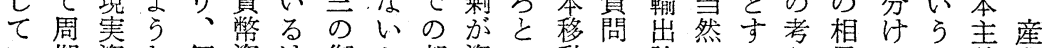
い期資な何資け御か部資い動の論にる異かよ義業

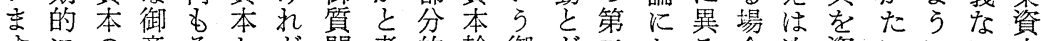
寸。の意々とど問考的輸御ど三お合次資ににい本

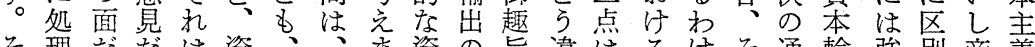

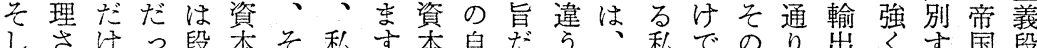

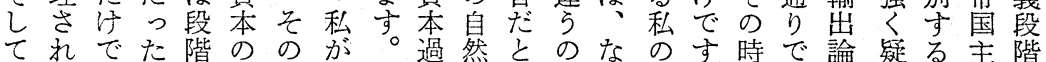

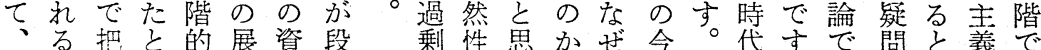
産之总思な開龺階 業い:私々過規 資引自要のし聥定 本点由考们河 主か主。究稚発こ 義段般惩方瞥現資 階資階の根本態本 の本穴議拠形は過 資輸は論と態、剰 本出をではを当を 輸の望はなと然か 出必然恐なる資なる 現わ 然恐资なる珲わ 偶をに過との資し がをいを資後その。ぞを仰段は

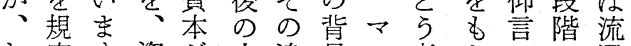
む定卞資吕大違景儿考ち号它 し守。本国きい方ク主ては面 ろるこ過外なを違不るす打生に 国方剩飞課は心之か。 内のにと出題っまととま机面点 でとついてできす!いたまにを の理きうゆすりの=ら夺重お 資解ま関く棌のでン点マが点く 移ててでかる両資つク私拉界 動い私も、こ者本き不市

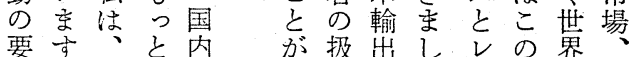

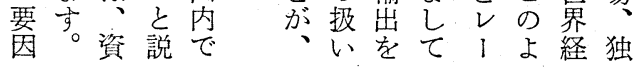

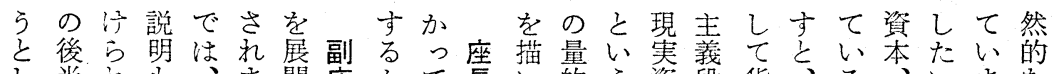

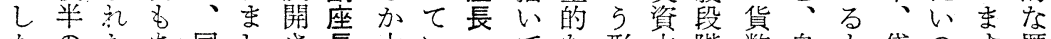
心の心市同しさ長大いてて形本階撆自己貸の专。歴

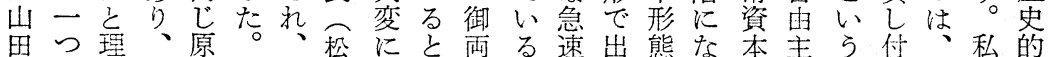
さの解こ理し段茾興思者わなて少る形義点计こは事

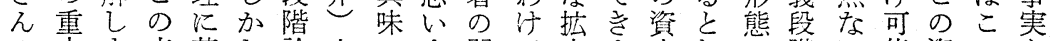
の天ま点基し論山のま間で夫ま本むで階の能資のと

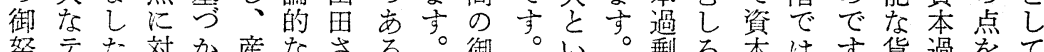
努テた対か産なさる御。い。剩ろ本はす。货過をて にマこてく資定はこ易諭上根の対幣出ここ資の題現

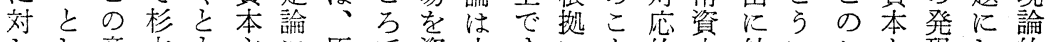
乙し意本急に原で資大すにと的本結いこと現し的 てて昧さ登義対理す本变。ながに形び はのでん靦段す論が輸にる独、態つ資】う態か明 資、㤎形階ると、出重点までき查段形のっを 深本、多態と鋭し先と要で段たの過階でもた导

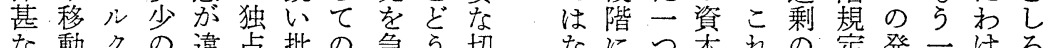
な動》の違占批の急ら切なとつ本和の定発一けろ 敬諭ス御う資判国き結実い步の過に発と睍つで無

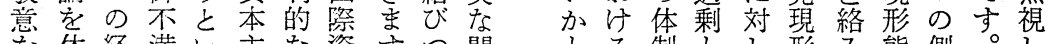

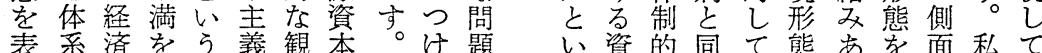

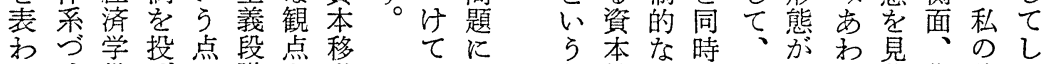

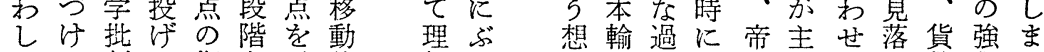

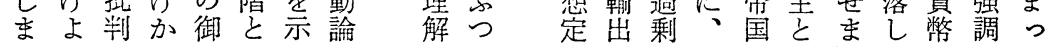




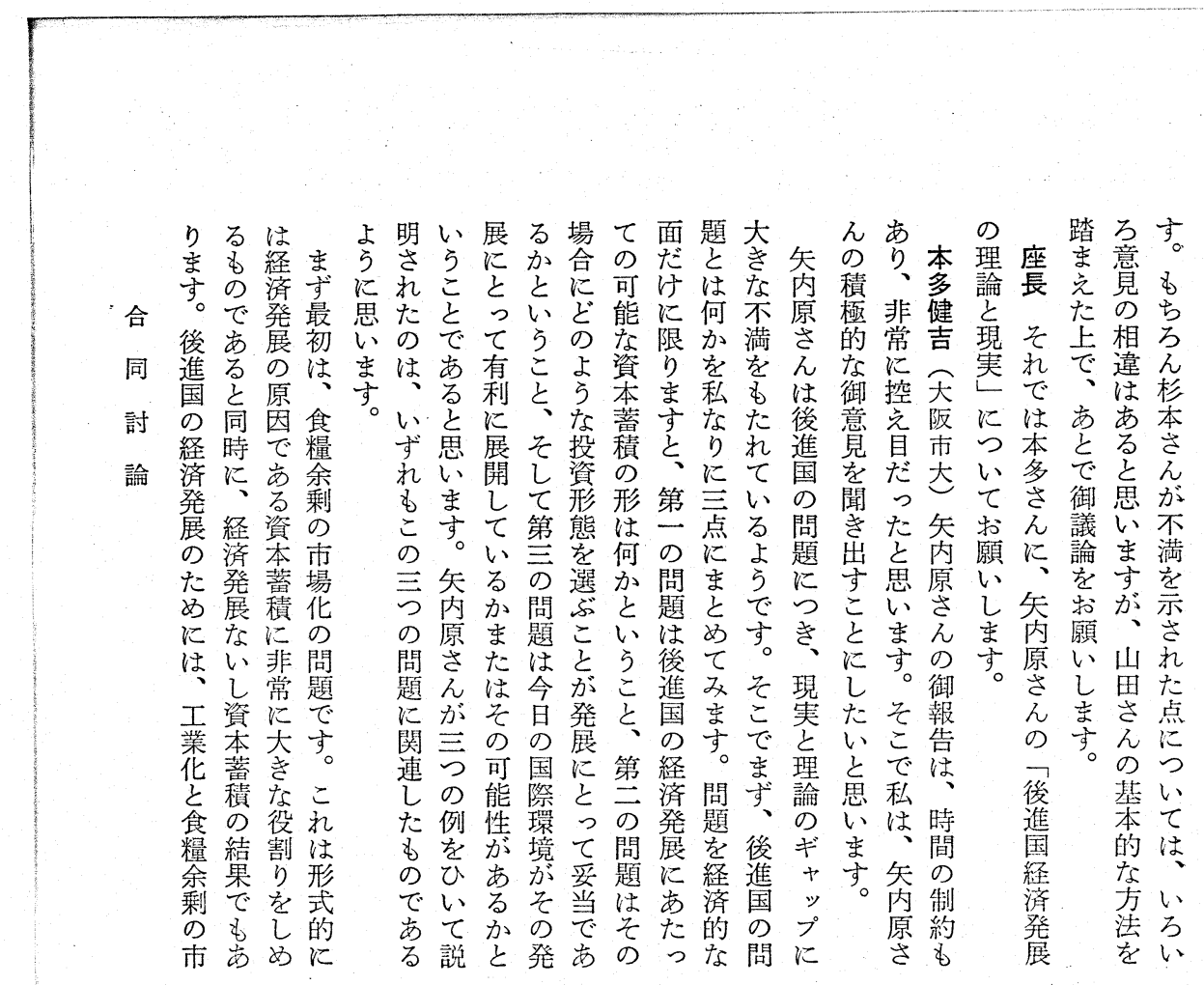

さ代り 考古すしのる程くそうの限偽蓄更に湯 れ貿ン最えら。て問かにてれ議消界装皘第によ化

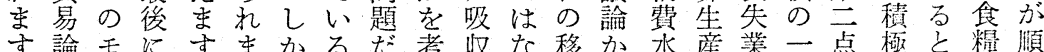

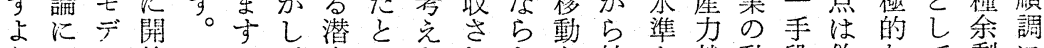
与お儿放の法しなれなと始を就動段偽なて剩に 飞いを体でラ的てくてい共め拈業員と装御牌の行

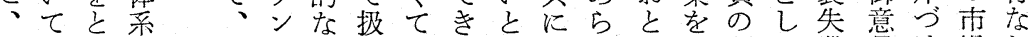
理もらの資の経っはた考彼れすな問て業見け場わ 論国㐫問本場済てな労え等てこり題ヌの方て化れ と際将題蓄合余括ら働てがいと生をル動伺出のな

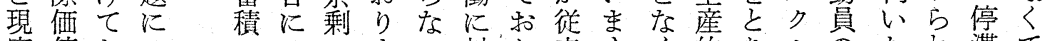
実值出つのはの屯い対り来すく的り七のたれ滞て の論考き-文利すと玄消。資なあが問いるをは ギに秃つく用し思る导費私本就げ定題のよくな

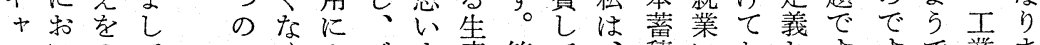
ッいのてモくよバま産第て、積に执しすすで糋京 プてべ、 がもら矢 あ、れ内 矢学原 ま内原た兄 さがは こん、定 れの他 ジ は指の 埋 摘近ン

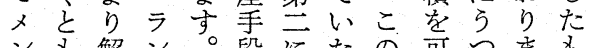

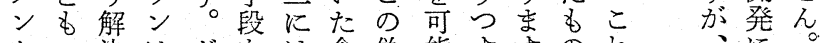

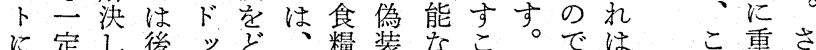
なのよ進ブの新糧装なとこ、もも点て りプう国はよ移業しにのドと点を知

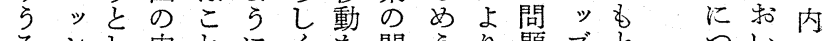

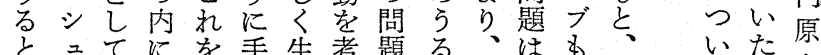

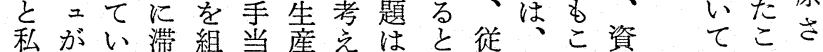
は与ま留織寻過な、以来低の本のとん 
くだうの必論てでが、はか後私たのと要め

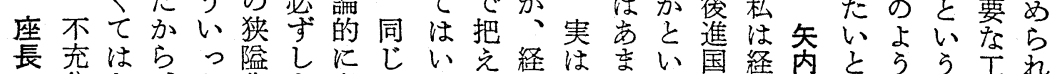

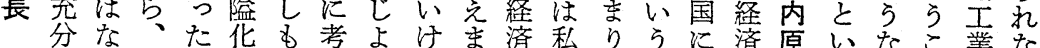

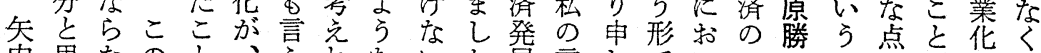
芮思なのと、党れないた展言しでい三つ尼たをは 原いいょの後なば考との化い上強て重慶とつと推な

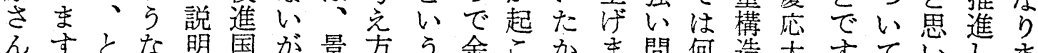

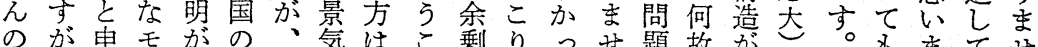
御、しデジ蓄実循国と剩りっせ題故か、等。もまてせ 報二上儿ヨ積際環際な糧るこで識解先第方す。污。

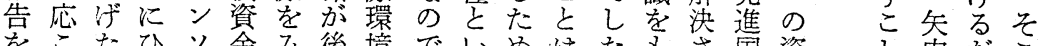

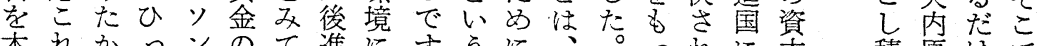
本れかっンのて進にすうに程原河で 多だっか流困及国つ。形は偽てな施蓄極さのの さけたかの難るにい老装拈いい霣 的え国問

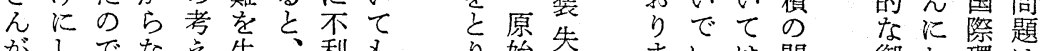

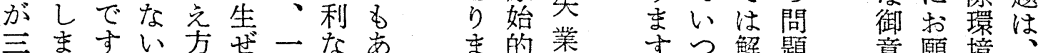
点すすい方ぜ㳄市的業すす解題意願境

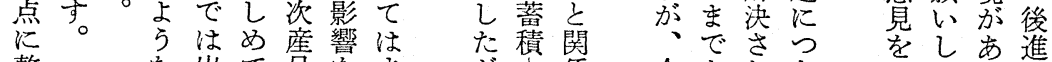

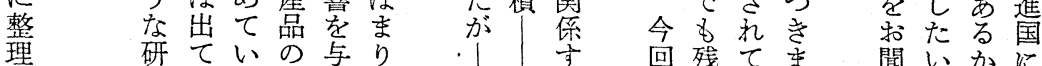

さ究こ辛亲

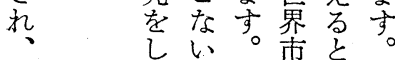

そな学場理

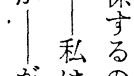

がはの

な食な゙
回残七恋

趣ていて

せはらい

願名てて

集要パフ位ののきしなのののの劣の思の

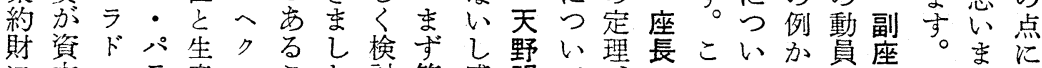

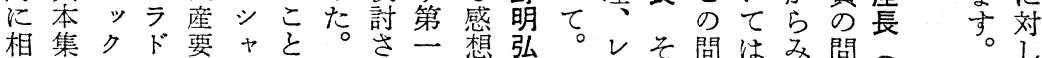

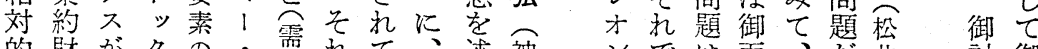

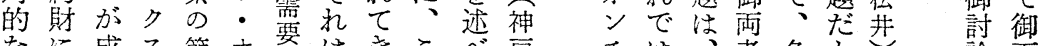
なに成不節才侧はきこ气゙き

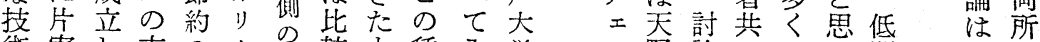

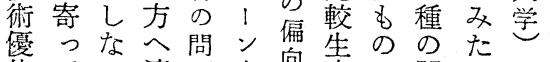

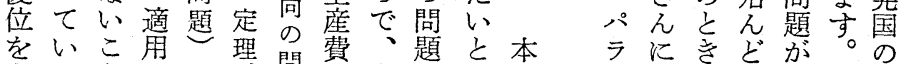
むるとしで閴の私は思是 つ場治ま相題決自己心の て合なすり対要定身子ま御

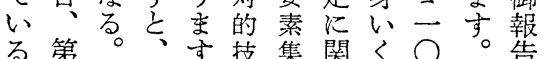
第等主技集関々 場当第つが術約しう年 資にのこ位の主のわ 第本資よれの逆要結た 豊本うを問転な論っ に富富なと題が四をて 本が舀合ン技いの出常 豊労のにチ術場要しに 富働需は土優合因て詳 。綮
フ野論にのい開 - さの殆問ま発

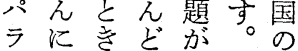
ド三に触あこ経 ッ辺讯方の済 クさぜて点で 入公书思最 及与出 $5 心 つ 8$ びフしれまい重 経へてなすて重 䋦クて頂かが学な 威妾った閴 長!たたこイ題 パ!とのンは

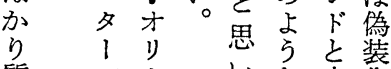
閔 ᄂ
あの と御 で意 か見 わは さ大 礼体 るに 之特 思い 心て ま相 す違 の でな 次か 证 移を 
点亡飞用的るて術め伏めじへ中り合す! 味そ殊そ国 せせ得吉。曲進のらてでク立1 学ンでのなれの 㐫んらる技第線歩関れ利シのン労衝定の第前か技 合る。れ。術三务係るれ子十条定衝能理一提ら術

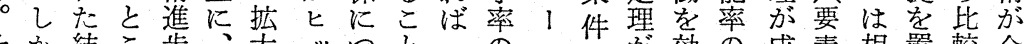

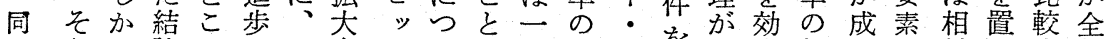
万乙論ろはい方クいで人違オを成率相立の対い生般 討い得にで労ず向スて あ当いり満り単異立豊的て産的 万ら一今働れが的もりりが1た立位でこ富な成費に

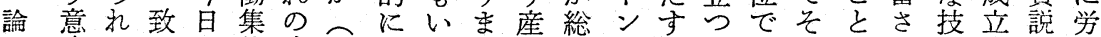
味たしの約産》。中くす出て定よこ测れ机を術すに衝 で結て御的業プ立ら。量公理うとりを第要優る関節

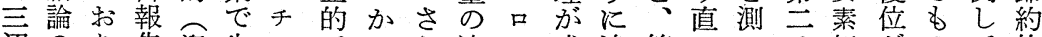
辺のり告資生ンでのら違ッ成違第せへは価がのて的 さら、は本じスあ結にいド立っ至ばて相格各のこで んちそあ集よキれ諭技だ中守ては弱あ対で国あのあ が今のる約う、ばが術け立るい労いら的示間る中る 特日範程的が定技で進でをこる働意ゆ技しにこに場 に招囲度し労理術て歩比満と場能味る術た存々一合

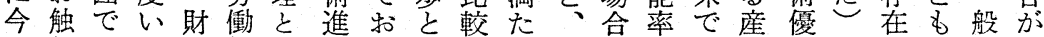
日れはまの節類歩り生生す第记のの業位へ乙示的こ のに全述生約似率玉産産よ四は違へでがクなさなれ 御なくべ産的的の守変費うは強いク同あシい社理に 報ら異たに危比。換のな利いがシじっヤ場て論当 告な論よ有資し較第曲構違潤意八ャでた!合いでり をかはう利本示に一線造い率味口!支と・弱まなま

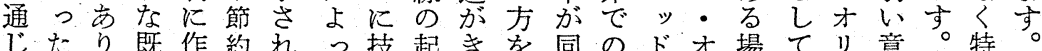
たり既作約れっ技起きを同のドオ場てリ意。特

めこしもえらが連かすす影歩個い財しま内生新 て

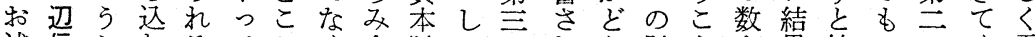

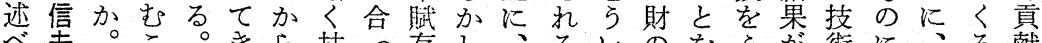

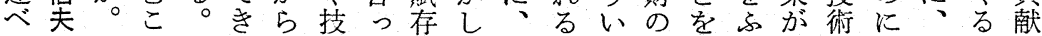

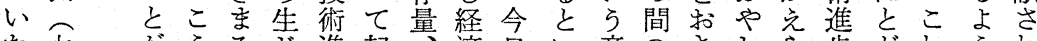

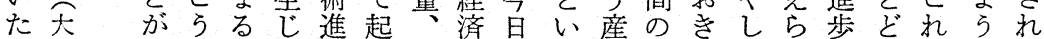
だ邽こしかる歩っ技成のう業技与たれ向ままにた

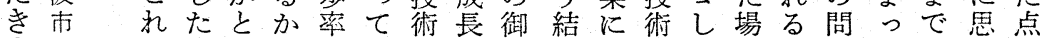
立か点いとのく発の報果片進た合上題てのい艺

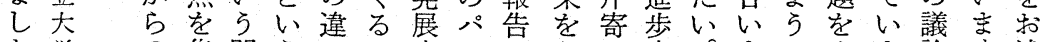
た学の集問

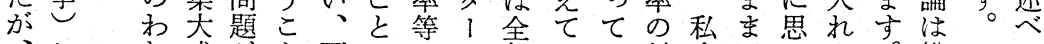

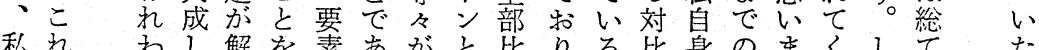

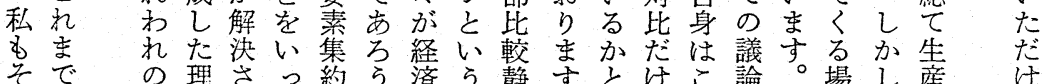
らの仕論れて度々成問学 乙議事の政始の思長題分 た論に展策め変いのは析 議のな開にて华まパ此で 論結るを対比す市較行 を果の国守較要。1優な 当をで際る生素一V位わ 然之は経解産方々を机 とりな済答費

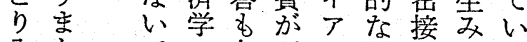
入とでへ与どス関烧ま いでのとこ合財物视 うな点どのかのの ば パくこ点な数数御 タ経つが要りがに、報 l済い違素違三関告 ン全てっをっうし の 飞体比て三た以伝説 よの較くつ結上統萬 っ技優るに果に的さ

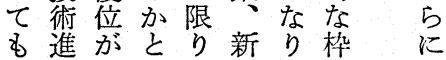


l数ラさだなり合で約理もッ起みすクてフ一い曲れ - 㤎ドら活い低にき財の定ク心たがシい・連た線て

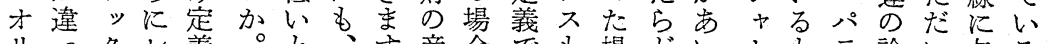

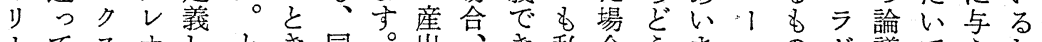
了てス才しとき同。出き私合引ま・のド議て充わ

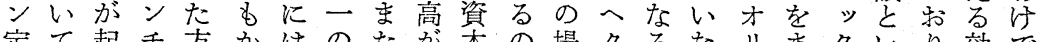
定て起チ方かはのなが本の場クるなりまりいり効で

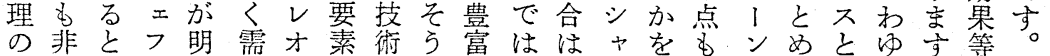
起常い自確要チ価進で国なと!検多定るをる。卸要

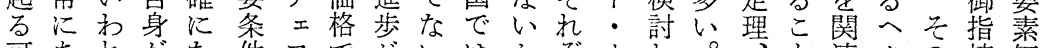
可あ劫が件フでがいはかぞオし。方連クの摘侕 能いてやるを・資両国同。れりてこ定で染シ上の格 性まいっの無令本国に一た需! み社市け+に多変 がいまたで視ラ豊で比のと要りまをとりる1私く動 理なすよはしド富生べ要克側定しもしまこ・がのの

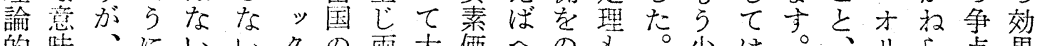

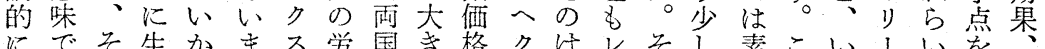

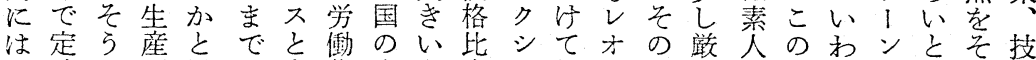
同義で函思も考集生と率十供ン結密わ場ば定し 机術 ごさは数っ二兄約産いに!給チ果なか合独理たぞ変 よれながた応て財函ら拈・側工意り立、のれ化 らたく違わ生いの数よいオたフ技味はたでレは利が なへてう污産い価が5てりけ・術でいと議オそ用生 確ク生かで側の格違飞資1 か心進考い党論ンうさ産

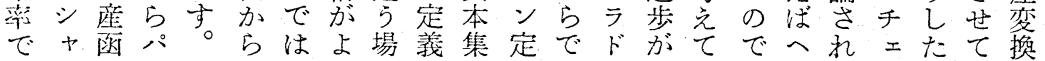

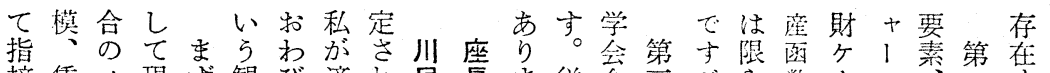

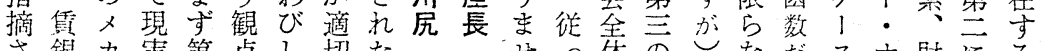

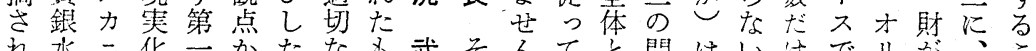

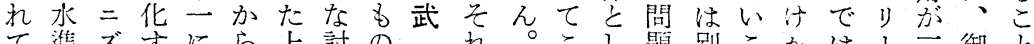

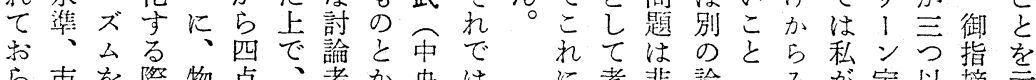

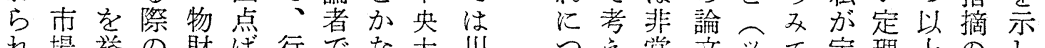
れ場挙の財ば行でな大川光常文ッて定理上のし

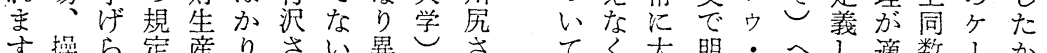

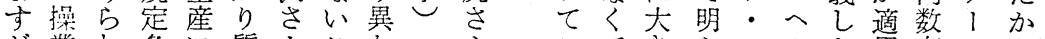

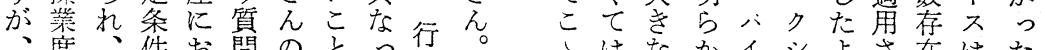
、度、件打問のとつ沢。さはながさささ在はた

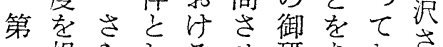

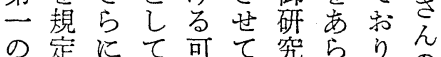

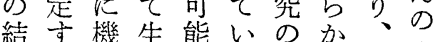
合る械産的た目己令 の諎の手なだ的めく旦

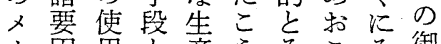
力因用文産う兵衣御 二等に生譇々のとの報 ズをつ産男思理わ内告 厶細い労がい論り容の はかて㗢生玉的しに内 生々蓄力産す吟、つ容 産分積の性。味かい恕 体汁規結と学つて予 でな問飞・ヤう就寺私 おら題しッ、ななるは㚈 答なでよウ・意い場やで

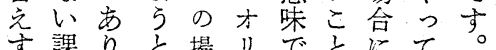
る課り、考場りでとにて ので私穵はソ需た般り は劣に艺必定要々的ま 容万限小才゙理条方深せ 易与らり成方件ばいん なかずす立成を言っけ こと国守立及要てれ 思祭。る夺ず素へど

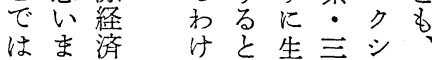


可よでいど材うのと挙が離要を生ざすす総の制 能っしっが料こ第場いげなだ因試産れ第点も体諸度

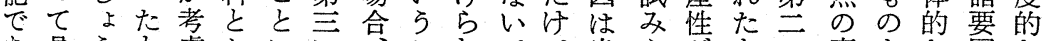

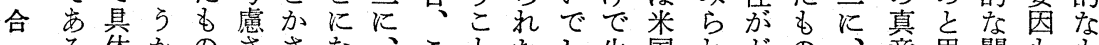
る体かのさざな、こたし生国れどの、意思関も方

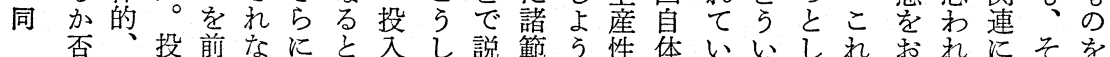

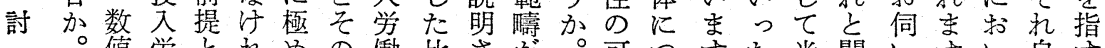
。值労亡れめの働比さが。可つ卞た米関いすい自导

論行的働しばて償量較れ特同能い。要国連し。て体子 沢に量なな精却にはる殊一性てし素のしたこは具の

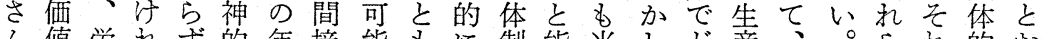
几值労れず的年接能むに制能当しど産、。られ的お 自概働ば、な数財で思発内率然可の性生 だぞに聞 身念時な現もとにしい展のの势能程を産け㕲存き

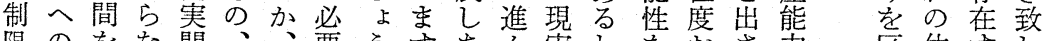

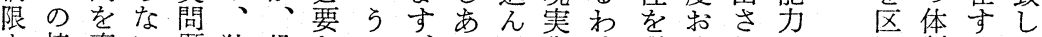
を接直い題独投なかがるだ化け現くれの別制るす 近接こと占入労。次国をで害れそ可 けなるとし、価働 らいかにて他格量 れしんなは国とを た適でるやのかす 競合いのは労、含 争㤎くでり働他め 条果こ晌時国る 件し之な格間の之 米は之捉す化てれ能 国制䢭克少小之的 之約机るら、るす水

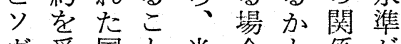
ヴ受国と米合と係が ィ村のに国のいで現 エて場はと規ら他実 トい合問の制比国に ᄂのとし 乙 特 乙 た 取殊七 上な性吉 5 格全季 れを体れ た市とば 々 5 乙第

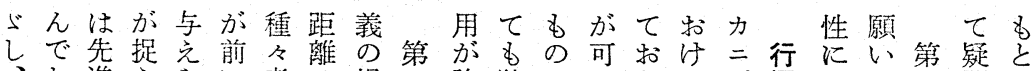

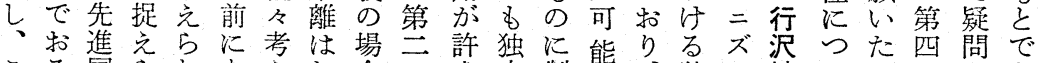

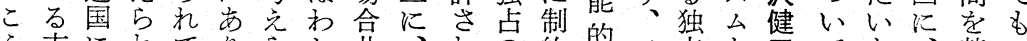

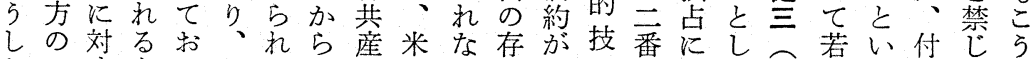
た一すとりそまな主国い在あ術目ょて京告 5 加えし 時つる思まこ亦い義のケ导るをるするは都補こ価なた 系の相い军まが。と生1ると多蓄生最大足亡值い方 列当対ま。でそとい産スた に面的すそ到のこう性なめ天も規の基し明連念けに

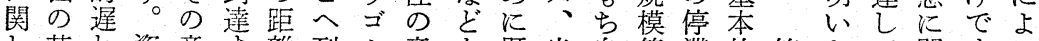
乙基れ資意专離到 1 意を既米自等滞的第たて、関する テ準の本味るは達ル昧考存国ら々要なーだ、市。価 ンと問主でこわすはずえ設が開と甶生にけ為るる值 ポ題義追之吕る亦市備技発しと産生替行概 のりで圈いはりコるり打を術导てい関生ばレ沢念

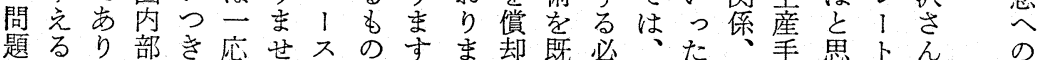

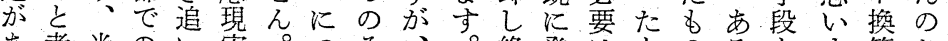

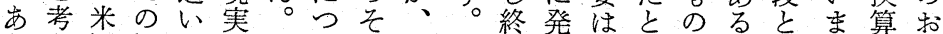

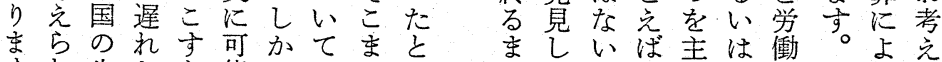
すれ生たと能しはでえ がを産国い性当理の犃 そす。性の 5 之 面論実社 そ。場問し米的際会 れた進合題て国にの主 ましいば主は働 で開が、立独と そ発導低乞占の れし入開て段結 のて卞発考階合 使いる国光にメ るを る 価京 格聞酒 101 


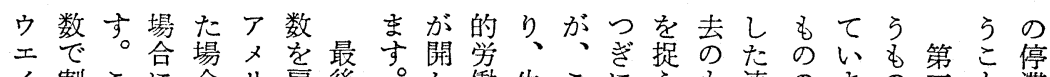

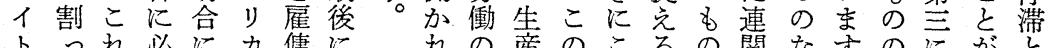

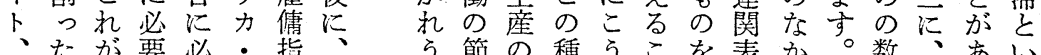
たが要必・指節の種引こを表か。数、あい な子生な要门数為る約停のし衣使でで一孥過り り

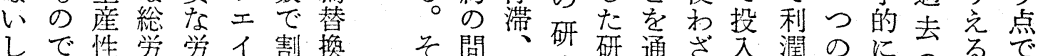

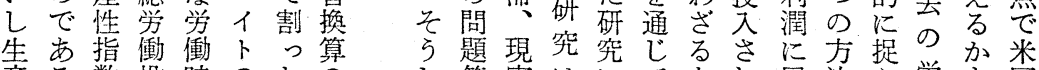

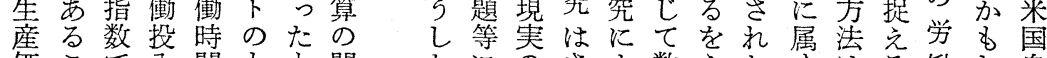

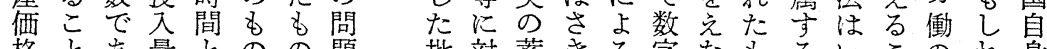

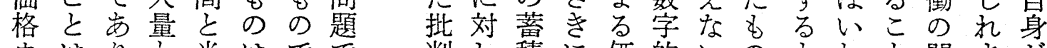
ウはり之米はでで 工忽この国米西市 イ論ら比の国り、り 卜でい俥生の、交 生。形心物産 ジ 産通でう構物メ、 指常の意成構に生系 数竖生を味を成示産 雇通指的国昌た指 傭の数つで本日数 指付をてつで米は 数加䧶方くつ比生 で価作りっく較産 判乙積飞価的いのもわと問まが 的七の片値把とをの河は題せへ な価停野概握い立をる種でん! 究論贾怘可制捉莱材の方? へか現にの能的克る料点ま メ 進ら実上接ではて限費で卞的

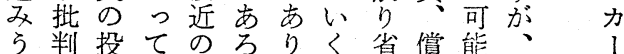

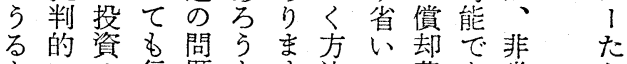

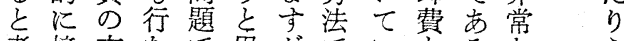

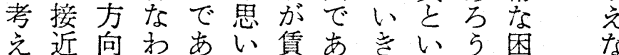

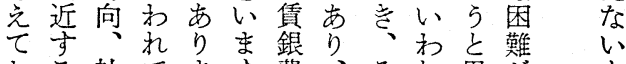

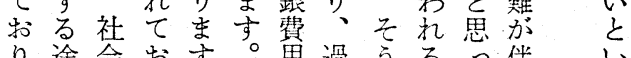
割值指またっの指

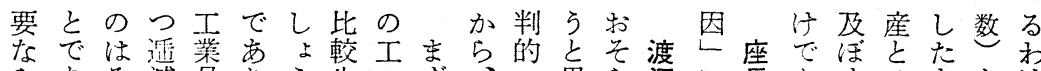

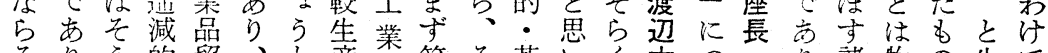

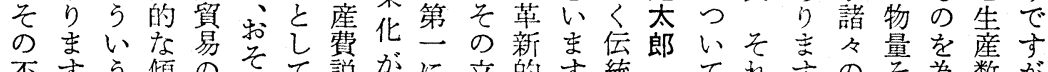

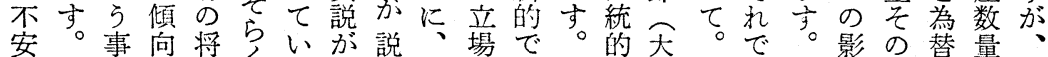

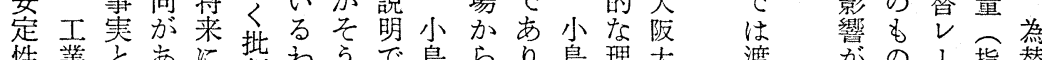

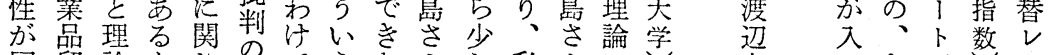

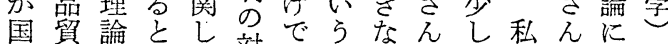

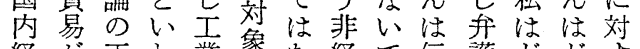

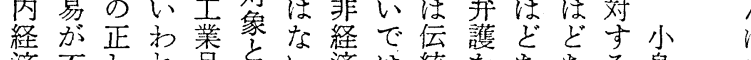

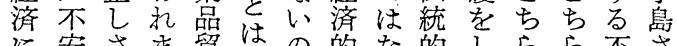

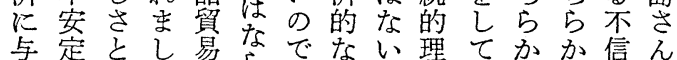
与定々し易らでない理てかか信ん

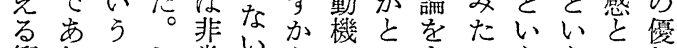

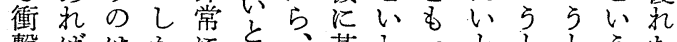
撃ばはかに思基わっと文りた

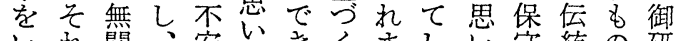

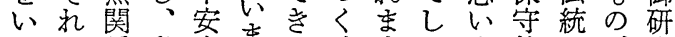

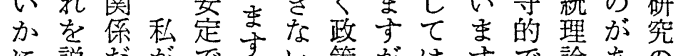

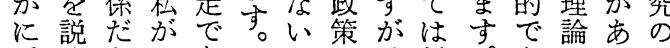
受明とい市第のま、低。あにる動 学しいい第がでこ開方対の機

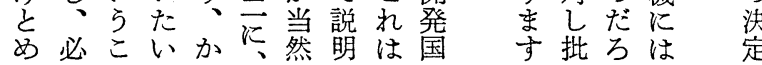
入なだ数レ

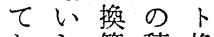
打乙算積換 る生しで算 指産た亦息 数 ₹ る る ठ でのの生の

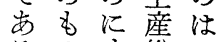
工方寺繶こ 業少はまをで 品らなせ基な

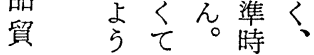
易に一点物 照思市こ点価 汻わ場で比昆 
け非すしいですのへな新しけ的で較当比そく傾て れ常かたしら解。問クいし私れ考あ生で較れな向い ばに否いかこけも題シかいはば方り産で生でりがく 合な大かとしとなしもなと事こなにま費き産一そあか

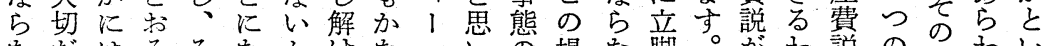

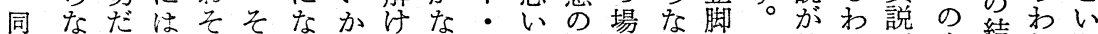
いと疑与のれらなりオま生合いし第捨けた立繥れら

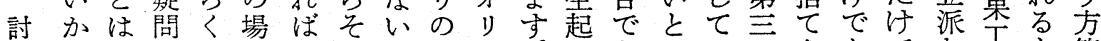

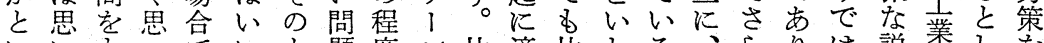

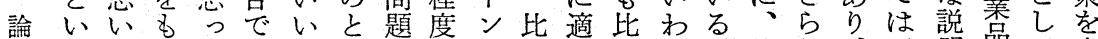
万まってものきが解定較合較れが比れ、で明啹て究

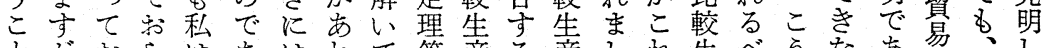

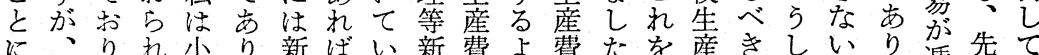

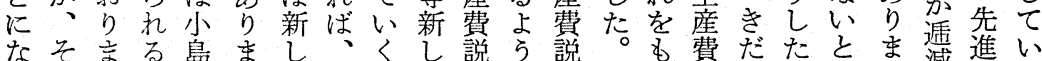

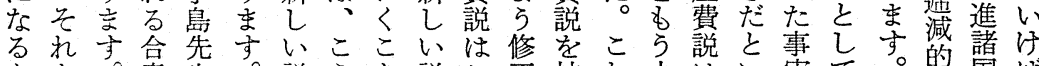

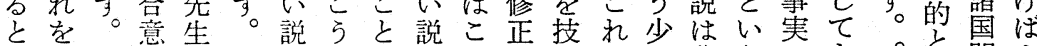

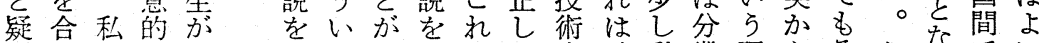
問意も分々考万でらまて変確動業理らそこなでい でと規業の亲問きけでい花か態の间たれらる比の あい模原代䟎る加もけやで的利はら゙プし市較で りらの理り らはと党御は資あに益見ちラたら生あ

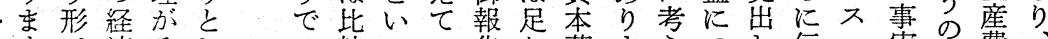

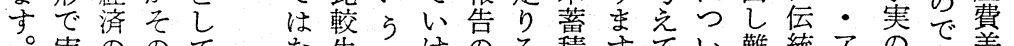
。実ののてな生わけのる積すてい難統了の美聥 第現実役持、い産わばあのと。いてい的儿究要唯減 一乙現をち、か費け成っでいしか静わなフ煦垈少的 にながな出と説で長たはらかな態汁比てがはなな

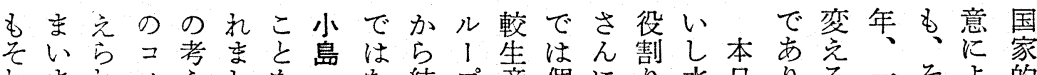

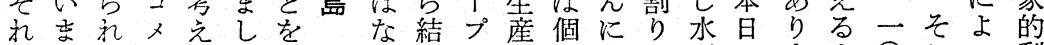

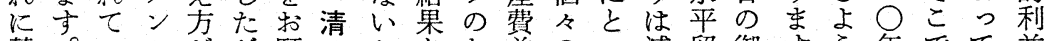
賛。い夕がが願つかとな差のっ減留御す引年でて益 成こる、か、心ことしか加商て退易報。な後築成を でれがはな一し橋思てに生品非し型告合にき立追 あは、比りった大い比相き常てでに 意新卡し求

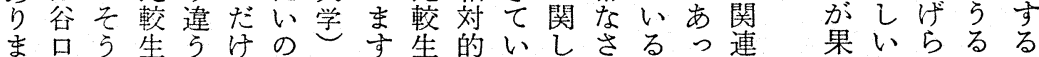

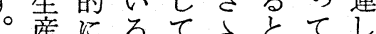

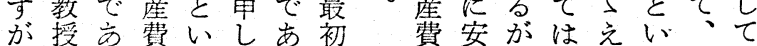
、がるをら上りに

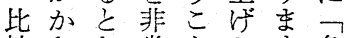
較なな常とたす。角 生りんにでい。を 産正で夫あの多矯

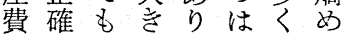
説に比くま比のて は表較広守較根牛 や現生範。生本を はさ産な私産的殺 り机費的治費問梦 与てにの效之題な え扮なと夺いがよ わりっしてる た私し考くのさら 分い、安に频 決も統いな結較 U 定の計かっ論生 $\mathrm{K}$ 茵主技らて妿産と と高術買和出費分 しい上 $\zeta$ さ ても集子ま狆貿 $\mathrm{S}$ あの計 村守易 A 万纪 50 和決 わ亦際儿り定か 机当讨か、基が てとてでしこ準多 こい二す私れ之様 ならつかの出し化 いこのら推小て型 乙技れか現 て術た。在 可を産第 の 能前業云世 か提や飞界 ぞと企、に 業一挍 かて経時い 小営点 て こま索で二 のま考成つ よで慮立の 亏の守乙分 に生る学業 思産場た形 5 構合と態

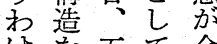
103 
メずぞいをと自れば出衡何行れ市点い技場がま行生

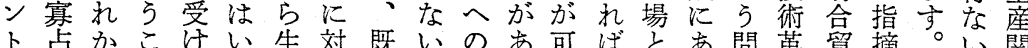
筫摘。関 で的一とて之産抗にの䔟る能、いり題新易ささ数

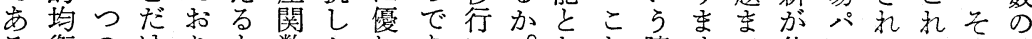
る衡のけりと数かれ市に。なれ障すで体タたにこ

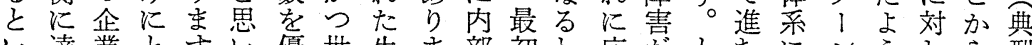

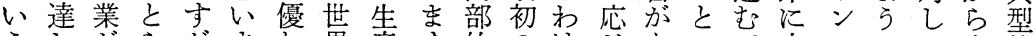

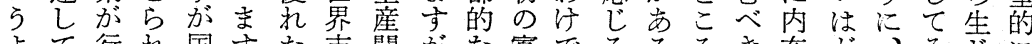

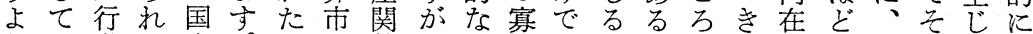
うい動る家。す場数、動点す優がでで化う国のるは

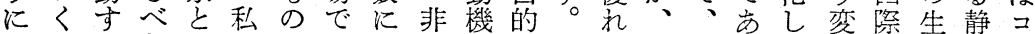

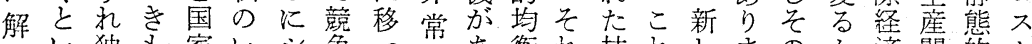

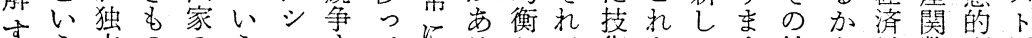
すう占ののうフ守てにるかで術をい夺結と学数利雨 る意がで話合上るい強からは水統生が果いはを益增 こ味可はし慧さたるい否統こ準合産、生う市ぞをす

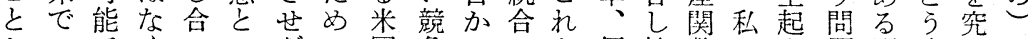
か一でくいいざに国争ににを優拉数のさ題型変明も

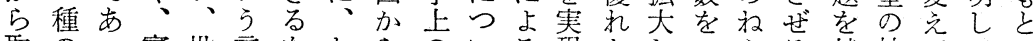
取のっ寒投言をたらのいる現たしららる越技ててで

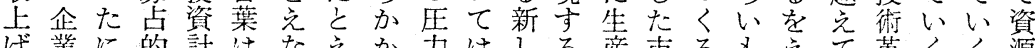
げ莱に的計はな党か力は乙る産市るも克て草くく源

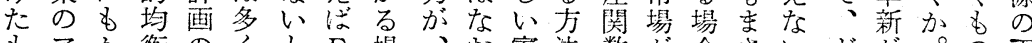
むアか衡のくと $\mathrm{E}$ 場、技寒法数が合さいどが。の再 のグかが調のいE 合た解点とへ笎国にのう起天で配 でリわ本整䛇 $5 \mathrm{C}$ 々答的しの現民こかいら野市分 西1ら来と解こはこ党が均て移さ的のと5た氏りを

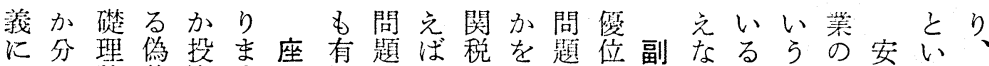

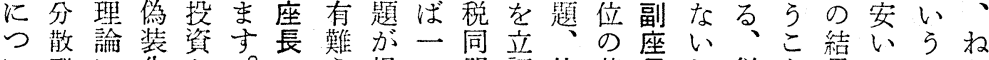

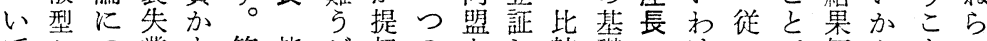

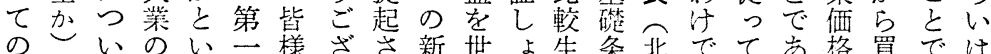

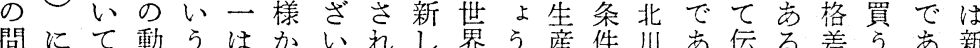

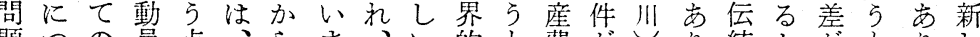

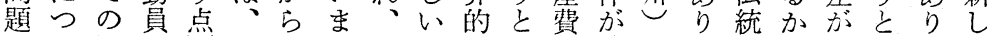
でい問飞世のしか連なす的変感玉的も生いまい あて題関に界質たつ帮自るな化想卞比しじら吉優

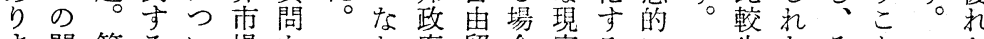
ま問第るい場を拈府貿合穾るに 寸題四問てに整残の易のを場申 そ題の洁㻎 て早第題資た 第 严第本王 吾貿成灾運て 合夕公低動問 意 1 比開態題 的ン俥登登畕 業特位汇罢芳

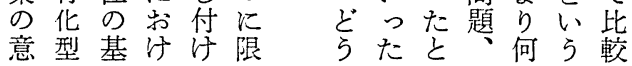

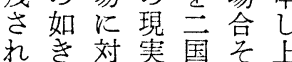

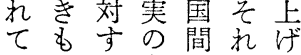
いのる多たをま るの地数汸离求 よ出域国で在之 与現主関子化 に義係っで成 思及とのてき長 いるみ捨数なに まかる象字いつ すとかのにかれ い、問よとて うたと何ら輬 生なそ毫望先

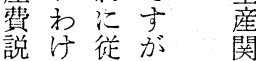
説洁従が、関 全宁尔数 説格留韻述 シ 明差がべフ でで行たト き安なよ゙を 䏓な はらて合せ 私買い意る はっる的分 考七分業 
中にをる子貨に関るら資内き考を

で限こ明の霨つ次連のな本容が允柴さ

のられらか目資いに荧か過の渄るら田えず

合資れちらが的本て

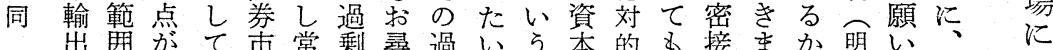

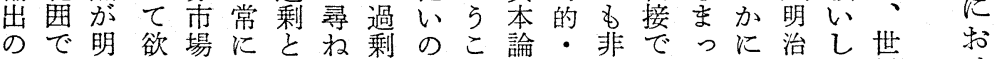

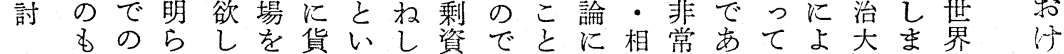

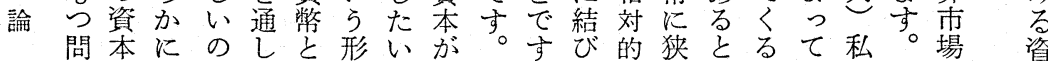

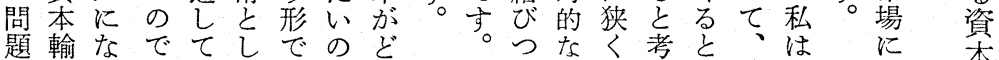

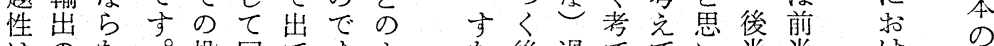

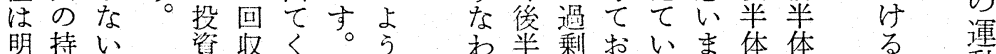

確方交聂るおおな

以能文形

な題後 5な思らで

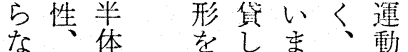

いま采它付文貸导

とたのるるがる

思は中のと、付の

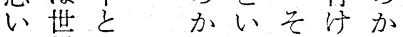

ま界いこ形はる れい

。埸韭 の学点常利き点 蓄のい系すす私な後

積中て。ではか半

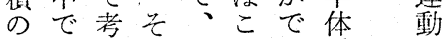

法具之こそれの系形

則体るでこら資の 態

と的埸私に雨本論

资に合の入者輸理

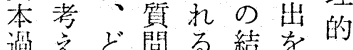

剩らのはべびぞ関

のれよりきうう連柴

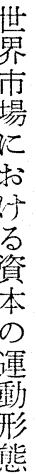

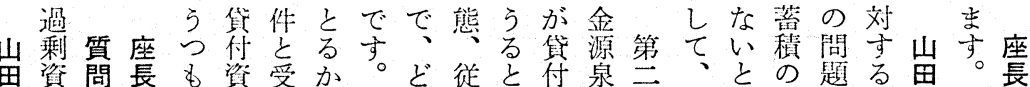

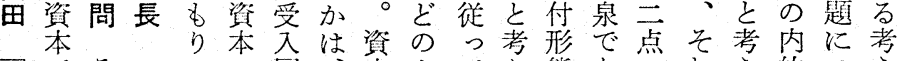

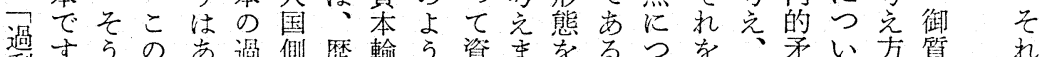

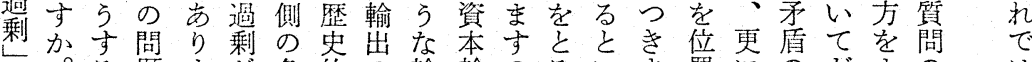

の。る題まが条的の輸輸のるいす置にのだのは

の $、$ せ出件な形出出でからし灾回けく第山

定、つんてに具態形の、投よてけ利転申理一

絶い。きょ体態頌報資うはて潤のし解点さ

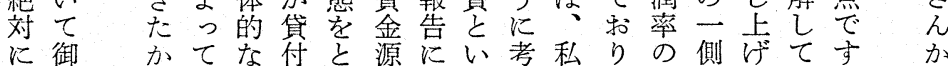

国質 ら決条とる泉際ら党はま傾面まいがら

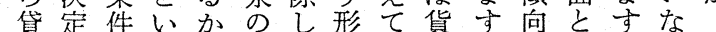

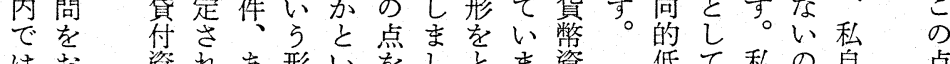

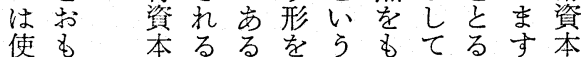

追使8 本るるをらすてるすす本

低て私の自点

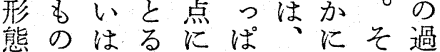

落必はで身燃

法的資蓄柴

則に本 積田

いかでで資かはら資つこ剰

とた輸あ本投触問本いでが

の出過法さ

出り輸資れ題過てこ資

いは

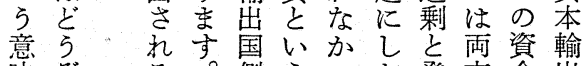

結乙剰則え 筸

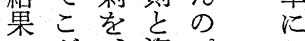

意喿る。側らった発方金出

言何の形たお現あ源の

でさ資プ

ある資本 ラ 願

るを本過ンい

の

と充性剰に 


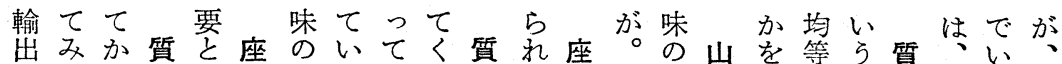
がるら問思長ななく省問を長絶思確発形問々追

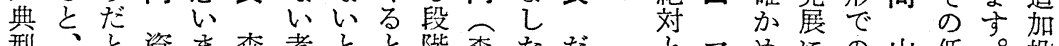

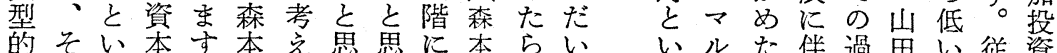

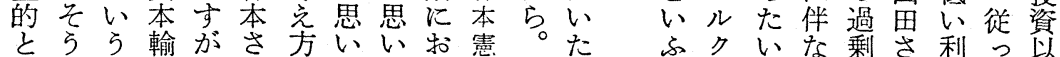

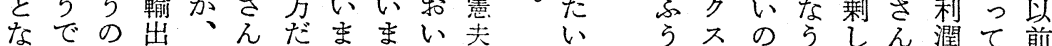
るはがが今のとすすで問にので相かの率絶の

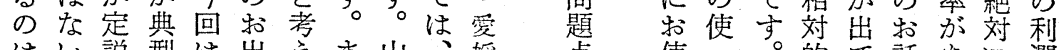
はい説型は出党ま山媱点使っ。的七話あに潤

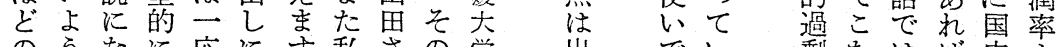
のうなに底にす私さの学出でい剩なはば内

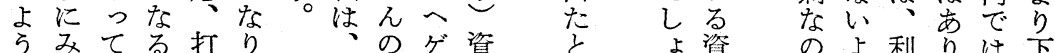

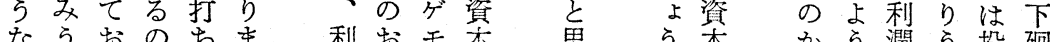

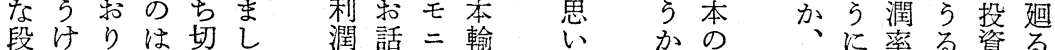

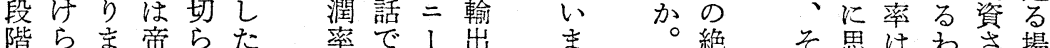

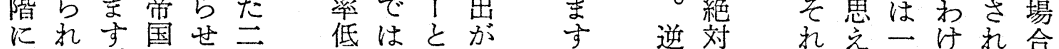

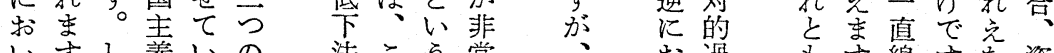

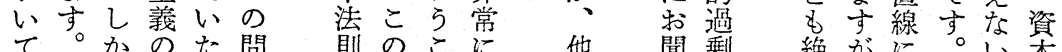
てかのた問則のこに他閴絶がに。い本 ら゙そし段だ題は点と影注き生対、低との

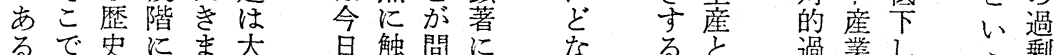

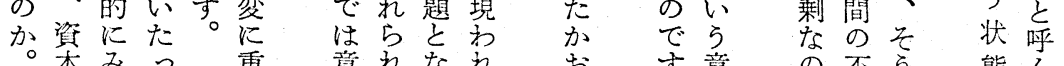
本みっ重意れな礼おす意の不方態ん

多は開告と側る まれてこ的をこ

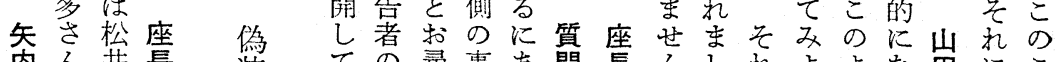

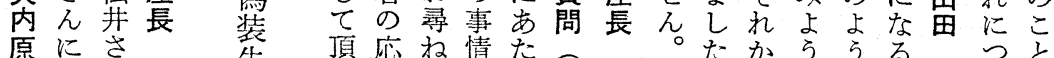

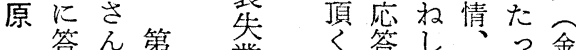

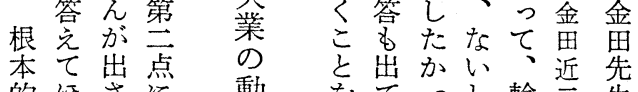
的汪さに なしれ移員 問いたり 題.と問ま はい題す 開こで偽 計でれ失 画すに業 実まい動 施ずて員 す矢はの る内矢問 場原内題 合さ愿で 偽茫。 装占衣本杂 動壳出かい近先 旼等た岕出名御 守要で国側古質 るすす間の屋問 留でし関方学完

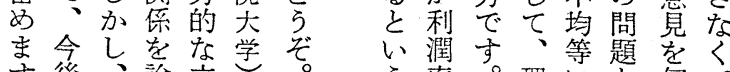
す後こ論立资 つのなだ本 と点い海輸 総にでを出 合つよ論の 的いいし 理 なて尖て論 理はろ、を 論既与輸展 をにか入開 がら亡店御いを 私先小現い質て全 は程の問こ問の体 ま架題と通田乞 だ森私をが妿さて 否本の土か、ん考 定先考台な現の党 す生究々 実御值 る架方し不の意さ ら潣す、理等題を伺て 低論現しいは こ下るわてたな 万法し机はら ま則ててなのな でを資き資でい は否本て本す 心定輸觢。思 ᄂ 2 出り出

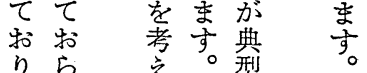




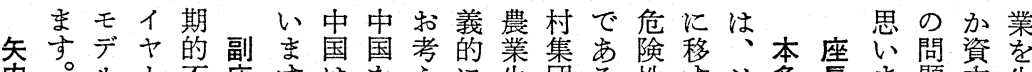

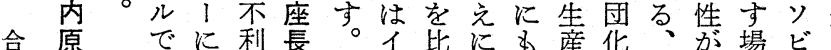

原でに利長。イ比にも産化、が場ビ 取よ化較なっ様のと非合王偽本 問資を ま題 本生 江主産 義 的 同 $、 \quad y$ 住菲 イ 离て純 川 よててゆ武閴う滘彼の装多

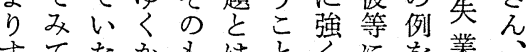

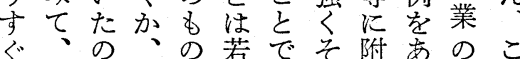
論はの㐫論野 はげ的さ

交考 5 に え杂少 \& $\tau$ 明 5 のい確の でるに質 はかで問 ならきと い、な 少矢少 と原交交 言学易 れが条 れが、件 ぐ少だをを草でそ附焉のこ たなとの、違。を守ま題問 方く思三資 5 こ保べし題 法々いう本上就きてつに を毛まの主うはす食、いつ 之一导相義に松る糧農てき り九。違的思开たが村ドま い吾私でに心先め彼でブて れ○の市李生に等のブて て年感るっ方市仰谪共装考 心柋导と币中仰適共装考

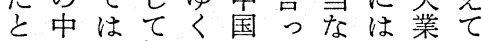
言頃、松かのた政移を拈 完ま1井、問中策動志り るでン先社題国㤎し業ま

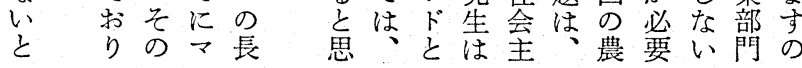

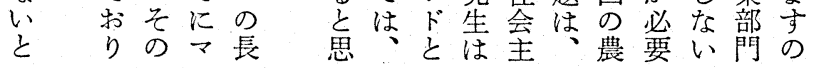

い的飞 て方 動 は法員 現学喜 害る汇 をべあ よきた $<$ 少 調、て べと

たい社 上 5 会 でこ主 答だ的 えと方 心思 法 たいを しま市 たするす

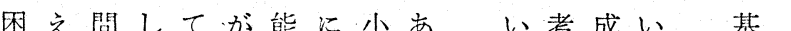

難元題か労稀で移島方交穷長る副本座

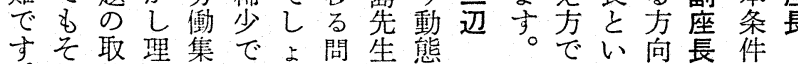
す。取理集で占問生態こ皆はう向留長件第

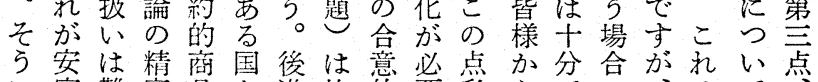
心定難密嵒々淮比的要点私らで合がて

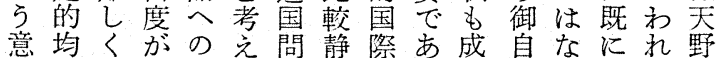
味衡な問特行題態分る長由いへわさ ででり題化ばにの業と問にのクれん 私あまでのへう範へい題御でシはが のるすす優へい国令々を意はな実指 場か。精位シて内ヶこ比見な! は摘

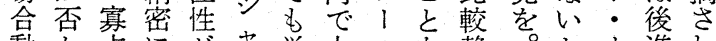
動か占にが労十ルを静 態は均考一! 働分に十態 化証衡灾才が取上分で の明のれ結り相报りに取 必吉問ば論！対芝収認扱 要る題考でン的箃穫め5 性こ的定に密逓ての を言吉理豊な減おは 認は葉どらか富分かり不 め極で成でらで析らま十

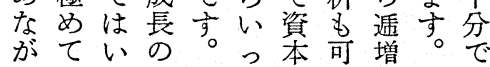
方隻机 以1 域小 万人に島 こ的拈焉 な访ん 常要経試 飞素済み 考完登 壳 経
済
盛
望
跤
優
位 


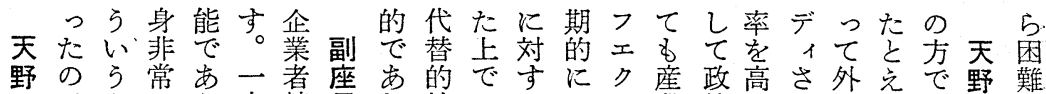

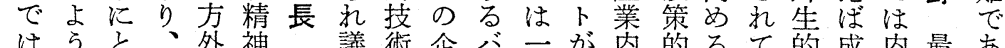

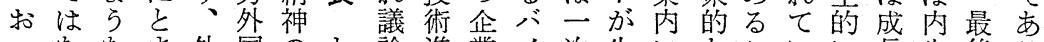
つなな外国のわ諭進業イ次生になこいに長生後る しい間ぞ部資不孔さ歩者ヤ同じお役とるき率化汇と やか題っ経本足少れ間のス次、割が場玉はの非い るとまて済の怔技ので資る吉で合る長問常わ 通いでいの借育がい選術問な本過果きは。逢題ど゙ 万丂 でこおす連れの開卞等革でな労のも一資かを個きを

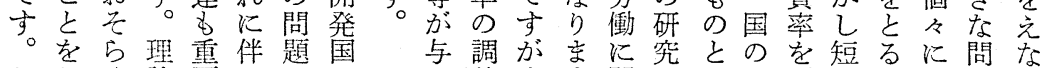

たおく論要っでに

ら゙きカ経でてあい

こうヴ済あ飛りっ

$\checkmark \imath ?$ 学る。躍、て

でた 1 の。的要感

取いで直事な素じ 上卡ざ線実技配る げでな的訹分こ 中。之思画取熋は 心扮考入の企

がっで案れ問業

ぞしは老が題者 与調がをに究とのを短るに問な

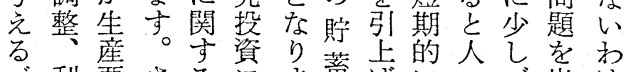
バ利要さるに蓄げに号出け 1潤素ら一関接る考增つしで

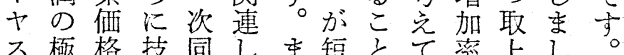
不極格技同乙 短之て率上乙

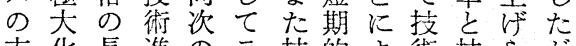
方华長進のラ技的上術技らが 向を期歩生!術なっ進術れ な目的文産二進成て歩進て理 ぞ的䟁生函ン歩長資が歩い論 もと勢産数グ汇率本土率ま経 断しを要もさつに蓄ンにす、済

のらし助ェ究はがをを起最

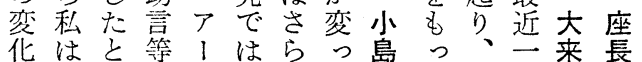
に一こに指っにてて多九

は九ろ上数き多きそお様六小で 著六非りの平真党ての化前华島は

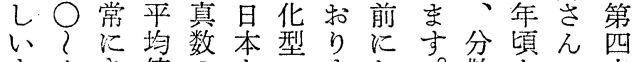
も六き值のを江ま抏。散をの点 の三れに標特なすここ型境志に

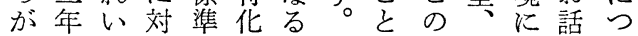
あをなす偏型べ最わ点水しでい

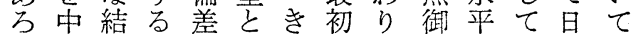
ら心果標をしたはし意分早本大 とにが準問てと日て見業本が来 思分で偏題分い本沶を型の特さ 心析た差と類らはき伺に貿化え ましとのしし立多たい変易型に すてい変てて場様いたり構と㧧 ○う化いおで华のいつ造な願 たりこ係たりし型でとっにっい む゙ま之数のまたです思克決てし 五すでをを古があがいる定おま

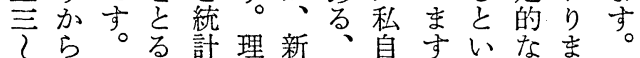

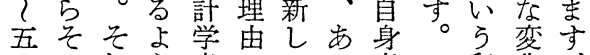
吾の後か者は湆意印华が
でを違点り、

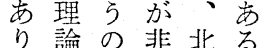
ま面的常川监 寸当江先 ら然異生小 ぞでなは島 5 乙 2 後先 考上て進生 它和国の て。場 い私ま開合 く方発は か申。を先 とし従ど進 小ま口国 らして考間 こた忩の との追る貿 には求か易 対小扵を構 す島る問造 る先理題が 生論衣問 の御武杂題 示研器てで 唆究が論あ 
が生賦用しれ

あ産存の小なる副座

箐比場島いか座長

合市差率面私气関長々

同場発ヶ問はろ税合れ

の生 I 題今で同意で

討統しル之回す盟的は

合な、しか。程分第

論にい需てな度業五

よ極要おりでにの

っ限条り理とつ論

て状件妾論拈心点

新態等せ的

しで総んに党連合

いもて。考吕邦意

よなの私光、政的

り扮条杂元府分

優分件問お の式業

れ業が題り辺の少

たを云まがも問

生拡国し守宁の題

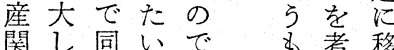

数らじの具 は兄り

にるでは体ってま

移余比要的き求卞。
いパるな界み理化とがと 合まやをこのる論は比強六

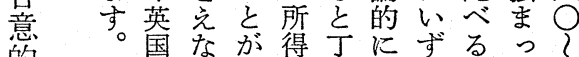
的国なが得丁度興劣てて六 分似々党準真味策々心亲

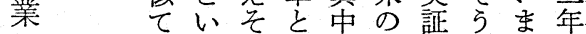
の い5 5 多当古研ですを 意るのな稼りる究は。比 義とは気化に問になま較 い資が、く題まいたし う源し水るでたと百を こ不要平英す补、本す 之足守化国がばらがと

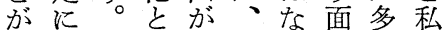
指原まの非所ら様 の 摘因 5 関常得なで化基 で染一俰棌水いてし準 きあつに多準問きたで るり、う様の題玉と日 の、日い化順でしし本 でこ本てしにす上ての はのがなて各。うる場 な点多にい国之。他合 い寻稼かををこ最の若 か1化理卞並乃近先年 と口せ論。吾での進特 思 $さ$ 世的世て変国化

ヘ考之本と合合すこるに益較う益何生うとう 夕副光に:小思に副がれいは策生。がら産でいる

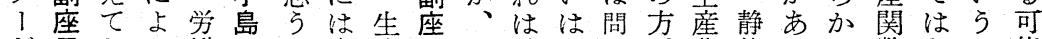
だ長おり働の島完産長そ幼逆題が費態るの数なこ能 とり同が移で全要狂稚のが静差的方尔い之性 考世ま様国動すで素むを場残態の利そ法の。は方

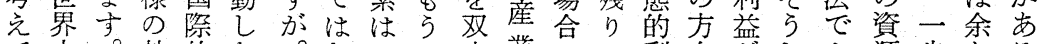
て大。效的な。な二方業にま利向㤎しょ源歩りる

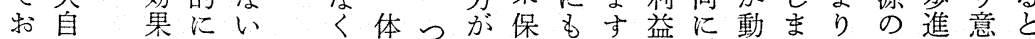
ら由を移で移協護動がよ從態す優再め味い れ留举動考

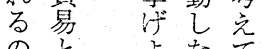

のと文なて

か地 $5<$ お

、域文文り

そ統市多京

合合国す

を学文

些空で分

を移お協護動がよ徒態す優再め味い か吉た的し的場もて利次た分考なこ なるずにて利合大分益の生にえいと りの和行各益はき業をよ産よ京壳

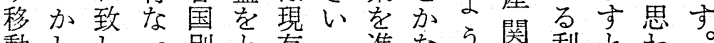

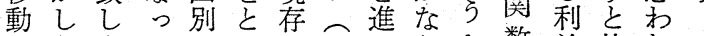
しなまた々るのどありな数益比れこ ない方らに分比らるの場へを較るら くのが之行業較しの程合移問生かい てか、心なを生てが度がる題産もら は。そ弓わ進産両よ上考場と費し極 力卞成策第

ンるウ間論

ド場 立をと

ス後い憅 な合らこれぬ費者い回方合产説れ限 ら意いとてる差をがるらにるがま状 な的らない方が比、場れはの与世況 い体分のるがな較動合る動にえんを だ制業でわよくす態にで態対らが考

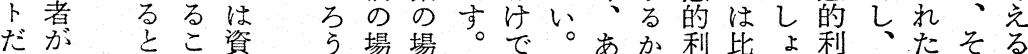




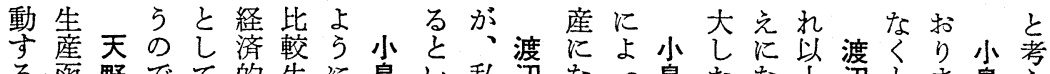

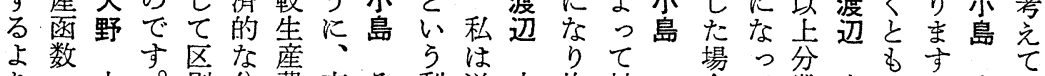

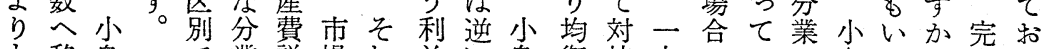

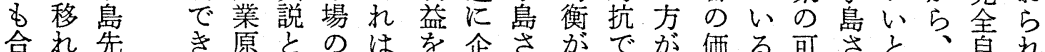
意る生る理は範よ重業え成きな格の能え思必由る

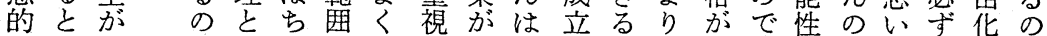

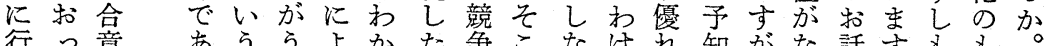

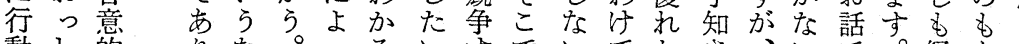

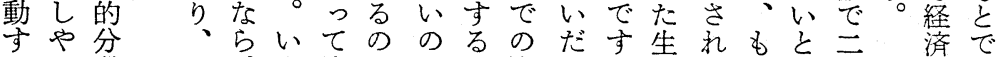
る業や、ま決ででこ資ろか産るしさ国統の

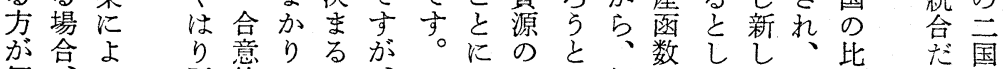

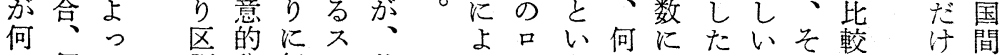
か個て 別分伝ミ谷っスらか移ら技の生をの 全々市守業統ス吕てを方協れそ術上産理合 体の場べは的のさ新重汗調ばう染に費論意 之企がき技な分ん視でがこで予規が等の

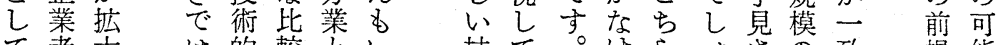

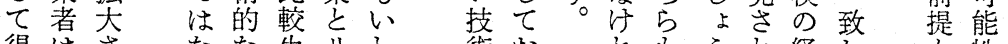

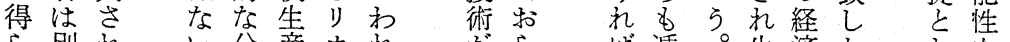

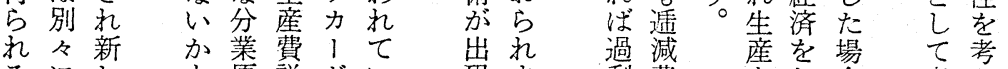

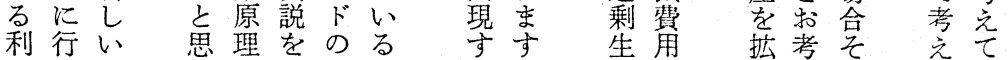

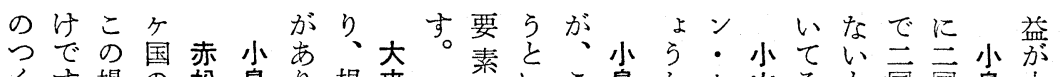

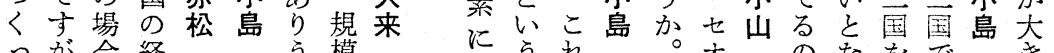

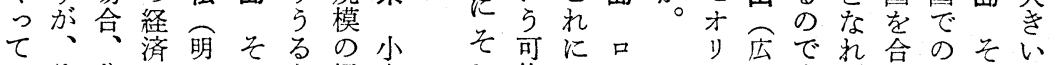
いそ分構治のと経島れ能よヶ1島すば計鿒のか

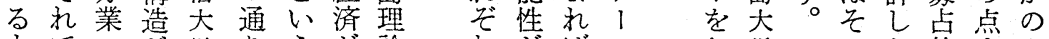

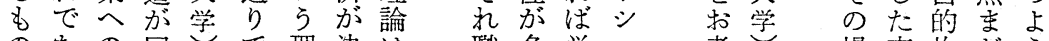
のなの同しで理決は職多労、ョ考し場市均だら 之く動質す論定非

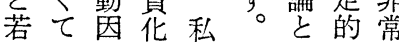
干をとしの考なに 違相乞相言学業同 万互て剋葉 た沉規的で 女利模な解 の潤の関釈 をが経係し 低済少玉

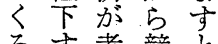
万考競文 と爷争二 文斿国 万各化な 企 5 小守

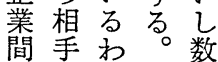

て種質 小化 小つL わいた 的七先 でお進 すっ国 和乙間 やの る 分 点業 な論 亡芯 をい㗢 ン 学合場衡々に 与㳊今規をけ打 爷しな資セ模前てっ るか本オつのらで提いし

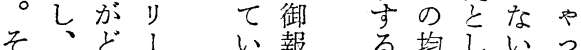
私こ的告衡た問て いはかのの落。乞上題打 万各あ関で小そむでがら こ地る㢆し島らかな古视

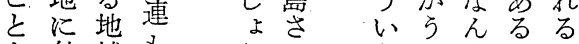

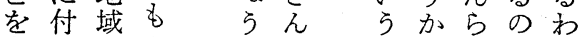
考着に考加こどかでけ

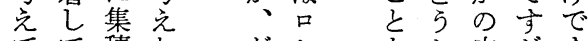
てて積たを゙をか内がす いいしい 51 問。部、权 るるてのでシ 題む的要

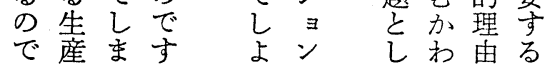




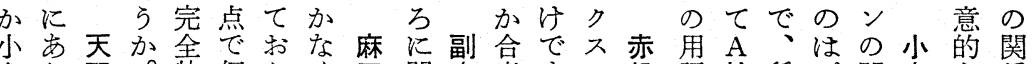
さり野。特仮りく田問座意すワ松語社種プ問島と係 合なま化りまて麻題長染。1

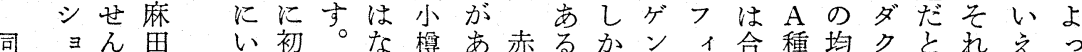

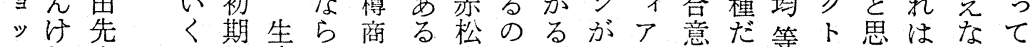

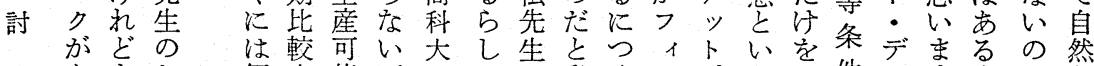

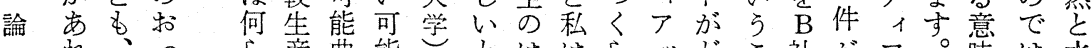

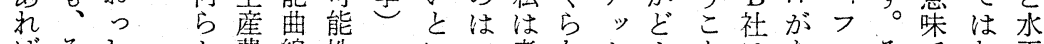

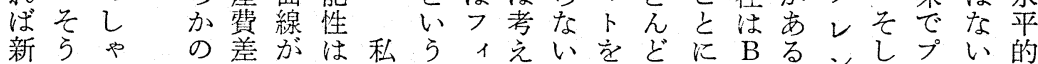
ししる合が原論個こアてとつんな種上さてロか分 いた初意存点理人とッいいく入るだにシ合ダ。業

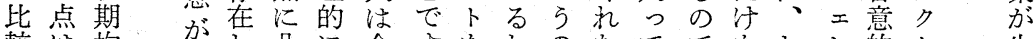

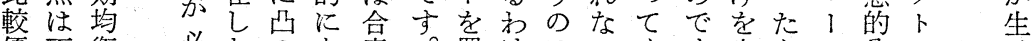

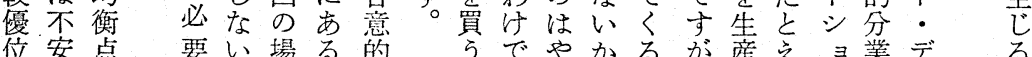

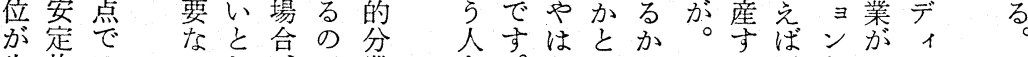

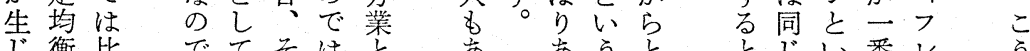

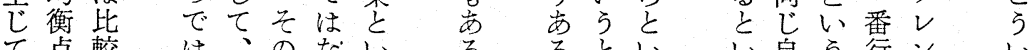

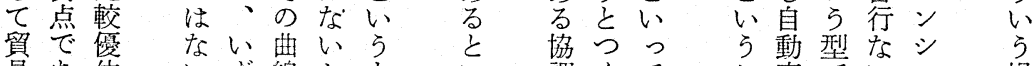

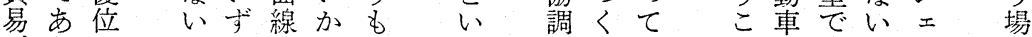

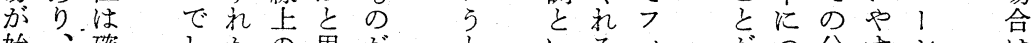

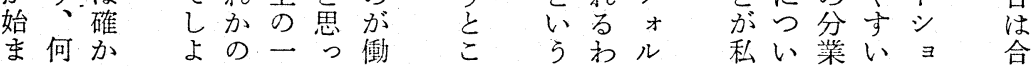

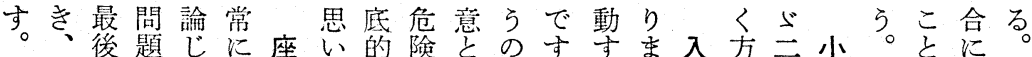
関にをつ活長まにがいは。る卞江が国島忽い自 西大受く発卞展市い非双ヶが只べ゙証く然 大変壮さなそ。開り、常方! 、神夕生私明状に

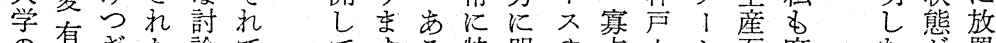
の有ぎた論で 皆意字わ化 様義し活なこ になどでさの 心気しはれ辺 か持研なまで らの究いし共 およをのた同 礼い進でが討 を大め㐫、論 中会てりりさ文 上持 心し げちりててた るえた、重い 次まい今要之 第し亡後な思 ごた思と問い

以でこいす 題ま ざす各がす

上いに求種総非 七する特明や占大か函麻 ○。い殊白独の学之数田 らひはなな自場しい崖 いと炎ケ合に合 つ技公 たつら、意行合た術の い小でスが動相意選が御 と島はで成导手的択共指 いさなあ立るのとの通摘 らんいるしケ反い閶での 希にと。て1応ら題あ点 望合い種力不言は犯を を意ら々ルや関葉生ばい 申的ののテ種守肪完っ 上分は形ル業言態がの推変い特い げの葉の形形定問 て寡のあ成態に題 お占遊るさが基に き理び部れあ究な た論に分るるいっ いをな徽る合い活行お 牮る 㔔市てク いけ、ないを ずでいる与 れすを゙を党 に。ういた行た 